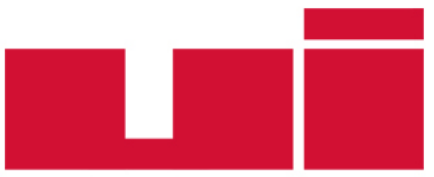

ULLUSLARARASIILIŞKiLER

Yayın ilkeleri, izinler ve abonelik hakkında ayrıntılı bilgi:

E-mail: bilgi@uidergisi.com.tr

Web: www.uidergisi.com.tr

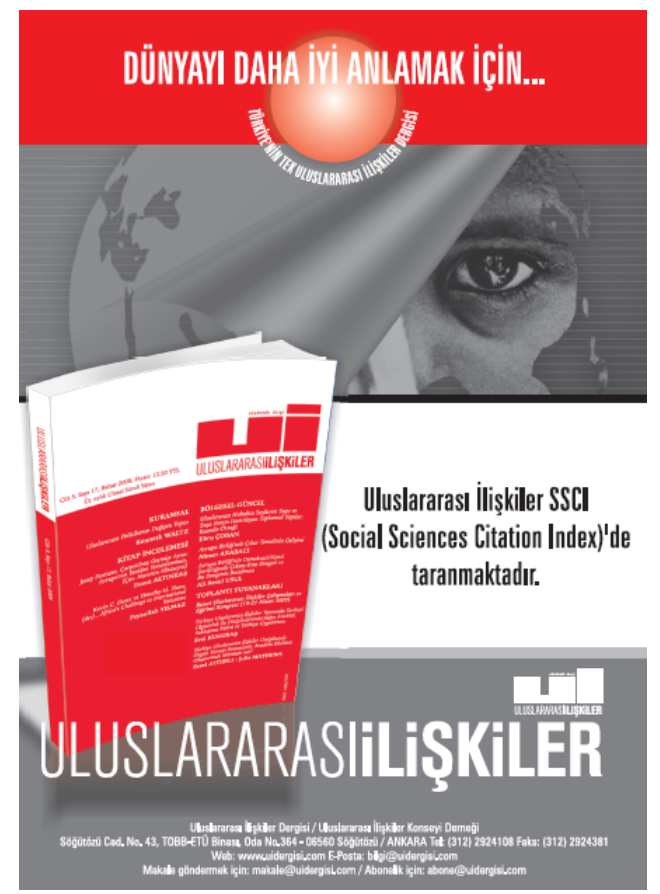

\title{
Uluslararası İlişkilerde Özür Dilemek: Özrün Kurami
}

\section{Erdem ÖZLÜK*}

* Yrd. Doç. Dr., Selçuk Üniversitesi, Uluslararası İlişkiler Bölümü

Bu makaleye atıf için: Özlük, Erdem, "Uluslararası İlişkilerde Özür Dilemek: Özrün Kuramı”, Uluslararası İlişkiler, Cilt 11, Sayı 44 (Kış 2015), s. 51-78.

Bu makalenin tüm hakları Uluslararası İlişkiler Konseyi Derneği’ne aittir. Önceden yazılı izin alınmadan hiç bir iletişim, kopyalama ya da yayın sistemi kullanılarak yeniden yayımlanamaz, çoğaltılamaz, dağıtılamaz, satılamaz veya herhangi bir şekilde kamunun ücretli/ücretsiz kullanımına sunulamaz. Akademik ve haber amaçlı kısa alıntılar bu kuralın dışındadır.

Aksi belirtilmediği sürece Uluslararası Illişkiler'de yayınlanan yazılarda belirtilen fikirler yalnızca yazarına/yazarlarına aittir. UIKK Derneğini, editörleri ve diğer yazarları bağlamaz. 


\title{
Uluslararası İlişkilerde Özür Dilemek: Özrün Kuramı Erdem ÖZLÜK*
}

\section{ÖZET}

$\mathrm{Bu}$ çalışma son dönemde yaygınlık kazanan "özür dilemenin” bir ilişki ve disiplin türü olarak uluslararası ilişkiler bağlamında hangi açılardan ve neden önemli olduğuna ve daha detaylı bir şekilde konunun ele alınmasının gerekliliğine işaret etmektedir. Özrün, dileyenin kim olduğuna ve hangi gerekçelerle ifade edildiğ ine bağlı olarak çok farklı türleri vardır. Ancak bu çalışma sadece "uluslararası siyasi özür” ya da "diplomatik özür" olarak adlandırabileceğimiz, bir devletin başka bir devletten özür dilediği durumları tartışmaktadır. Çalışmada öncelikle özür konusundaki tanım tartışmalarına ve özrün boyutlarına değinilmiştir. Özrün, materyal/pratik, normatif, pragmatik ve yasal olmak üzere dört temel boyutu olduğu sonucuna ulaşılmı̈ştır. Ayrıca devletlerin neden ve hangi motivasyonlar üzerinden özür diledikleri ele alınmıştır. Özür dilemenin hukuki ve siyasal olarak uluslararası ilişkilerde yaratacağı etkilerle ilgili eleştirilere de yer verilmiştir. Son olarak ise özür dilemenin Ủluslararası İlişkiler çalışmaları açısından yarattığı etkiler ve başta devletin rasyonalitesi olmak üzere kuramsal çerçevede ne tür açılımlara yol açabileceği tartışılmıştır.

Anahtar Kelimeler: Özür, Siyasal Özür, Özrün Kuramı, Rasyonalite, Devlet.

\section{Apologizing in International Relations: Theory of Apology}

\begin{abstract}
This article deals with the increasing importance of apologizing in international relations in the last three decades. Apologizing has many dimensions depends on who is apologizing and why. However this article discusses the situation in which state apologizes to another state that we called international political apology or diplomatic apology. After touching upon debates on definition of apologizing and dimensions of apology, we claim that there are four dimensions of apology: material or practical, normative, pragmatic, and legal. This article also tries to respond to the question "why states apologize?". Additionally debates on apologizing and effects of political and legal consequences of apologizing have been pointed out. Finally we discuss impacts of apologizing on International Relations discipline and seek to answer to what extent apologizing bring about theoretical development in IR especially in terms of the question of state rationality.
\end{abstract}

Keywords: Apology, Political Apology, Theory of Apology, Rationality, State. * Yrd. Doç. Dr., Uluslararası İlişkiler Bölümü, İİBF, Selçuk Üniversitesi, Konya. E-posta:
eozluk@selcuk.edu.tr. 


\section{Giriş}

Uluslararası İlişkiler disiplini, yaklaşık bir asırlık geçmişinde daha çok devleti merkeze alan ve Yeni Gerçekçi ajandanın kavramlarıyla uluslararası ilişkileri açıklayan bir çalışma sahası olarak Pozitivist ve Anglosakson bir kimliğe sahip olagelmiştir. Ancak küreselleşmenin beraberinde getirdiği etkiler, Soğuk Savaş parametrelerinin yetersizliği, disiplinde yaygın şekilde kullanılan "evrensel" algı ve tanımların sorgulanmaya başlaması, disiplinin gündemini çeşitlendirmiş̧ir. Yeni bakış açıları ve kavramlarla disiplin hem paradigmatik hem de terminolojik açıdan zenginleşmiştir. Bu değişimin bir uzantısı olarak 1990'l yı1lardan sonra, uzlaşma, tanıma, tazmin etme, zararın karşılanması, doğruyu ifşa etme, affetme, onarıc1 (restorative) ve cezalandırıcı adalet (retributive justice), güven, yatıştırma gibi kavramlar da disiplinin gündeminde tartışlmaya başlamıştır. ${ }^{1}$ Disiplindeki bu değişimle birlikte giderek daha çok ele alınan başlıklardan biri de özür dilemektir.

22 Mart 2013 tarihinde İsrail Başbakanı Benjamin Netanyahu, Mayıs 2010'da Mavi Marmara gemisine yapilan operasyonda "can kaybina neden olan hatalar nedeniyle" Türk halkından; 2000 yılında Papa II.John Paul tarih boyunca Katolik Kilisesi’nin işlediğgi suçlar nedeniyle bu suçlardan mağdur olmuş bütün kesimlerden; Avustralya halkı 1999 yılında bir kampanyayla Aborijinlere karşı uygulanan muamele ve asimilasyondan dolay1 Aborijinlerden; 1998 yılında dönemin BM Genel Sekreteri Kofi Annan, Ruanda'daki soykırımı önlemek adına yeterince gayret göstermeyen uluslararası angajmanın yetersizliği nedeniyle Ruanda'dan; ${ }^{2} 2010$ yılında BP, Meksika Körfezi’ndeki petrol sızıntısı nedeniyle ABD halkından özür dilemiştir. Örneklerden de anlaşılacağı üzere son çeyrek asırlık dönemde devletlerin, uluslararası örgütlerin, şirketlerin, halkların ya da devlet dışındaki diğer yapıların çeşitli nedenlerle kişi, gruplar veya devletlerden özür dilemesi yaygınlık kazanmıştır. Dilenen özürlere ek olarak, hala gerekçesi birbirinden oldukça farklı hususlar nedeniyle pek çok kişi, grup ya da devlet geçmişte yaşanan ve mağduriyetlerine yol açan eylem, söylem ya da politikalar yüzünden özür beklentisi konusundaki taleplerini sürekli güncel tutmaya devam etmektedir.

$\mathrm{Bu}$ durum konuyla ilgili hatırı sayılır düzeyde bir birikimin de oluşmasını sağlamıştır. Yapılan çalışmaların büyük bölümünde "bir özür patlamasının" olduğunu belirterek başlamak alı̧̧kanlık olsa da Uluslararası İlişkiler disiplini -devletlerin/hükümetlerin diledikleri özürler de dâhil olmak üzere- konuya son döneme kadar yeteri düzeyde ilgi göstermemiştir. Daha çok kültürel çalışmalar, tarih, siyaset bilimi ve kısmen de hukuk disiplinlerinin tartıştı̆̆ bu konunun Uluslararası İlişkiler çalı̧̧maları için ihmal edilemeyecek kadar önemli boyutları vardır.

Bu çalışma "özür dilemenin” bir ilişki ve disiplin türü olarak uluslararası ilişkiler bağlamında hangi açılardan ve neden önemli olduğuna ve daha detaylı bir şekilde konunun ele alınmasının gerekliliğine işaret etmektedir. Özrün, dileyenin kim olduğuna ve hangi gerek-

1 Elizabeth A. Cole, "Apology, Forgiveness, and Moral Repair", Ethics and International Affairs, Cilt 22, No.4, 2008, s.421.

2 Nesam McMillan, "Regret, Remorse and the Work of Remembrance: Official Responses to the Rwandan Genocide", Social E Legal Studies, Cilt 19, No.1, 2010, s.88. 
çelerle ifade edildiğine bağlı olarak çok farklı boyutları vardır. Ancak bu çalışmada sadece "siyasal özür” üzerinde durulmuştur. Son dönemde siyasi özür dilemek de oldukça yaygın bir fenomen haline dönüşmüş olsa da siyasi özrün herkes tarafindan geçerli bir tanımını yapmak oldukça zordur. Çok genel bir ifadeyle, bir devleti temsil eden kişinin ya da kurumun geçmişte yaşanmış bir durum nedeniyle bir kişi, grup ya da başka bir devletten özür dilemesi şeklinde tanımlanabilir. ${ }^{3}$ Tanımdan da anlaşılacağı üzere, devletin kendi vatandaşlarından ya da devlet içindeki bir gruptan özür dilemesi de siyasi özür olarak tasnif edilmektedir. Ancak bu çalışma sadece "uluslararası siyasi özür" ya da "diplomatik özür" olarak adlandırabileceğimiz, bir devletin başka bir devletten özür dilediği durumları tartışmaktadır.

Bir özrü, çalışmada bizim kullandığımız tasnif üzerinden, uluslararası siyasi özür olarak sınıflandırmak çok zor olmasa da, özrün içeriği, samimiyeti, geçerliliği ve pratiklerini tanımlamak ya da test etmek oldukça tartışmalı bir konudur. Bu nedenle, çalışmada öncelikle "özür" konusundaki tanım tartışmalarına ve özrün boyutlarına değinilmiştir. Literatürdeki bütün tartışmaları genel bir değerlendirmeye tabi tutarak özrün, birincisi materyal veya pratik boyutu, ikincisi normatif boyutu, üçüncüsü pragmatik boyutu ve dördüncüsü de yasal boyutu olmak üzere dört temel boyutu olduğu sonucuna ulaşılmış ve boyutlar pratikteki örneklerden de faydalanarak ele alınmıştır. Tanım ve boyutlarından sonra uluslararası ilişkilerde tarihsel örnekler üzerinden devletlerin neden ve hangi motivasyonlar üzerinden özür diledikleri ele alınmıştır. Ayrıca özür dileyen devlet ve özür dilemenin hukuki ve siyasi olarak uluslararası ilişkilerde yaratacağı etkilerle ilgili literatürdeki eleştirilere de yer verilmiştir. Çalışmanın sonuç kısmındaysa özür dilemenin Uluslararası İlişkiler çalışmaları açısından yarattığı etkiler ve başta devletin rasyonalitesi olmak üzere kuramsal çerçevede ne tür açılımlara yol açabileceği tartış1lmıştır.

\section{Tanım, Boyut: Özür mü Üzüntü mü?}

Özür (apology) kelime olarak Yunancadaki apologia'dan türemiştir. Sözcük, ilk kullanımında sosyal yaşamda karşılığı olan ve sıklıkla kullanılan bir sözcük olmaktan ziyade hukuki anlamlar ihtiva etmektedir. Antik Yunan'da kişi, kendisine yöneltilen suçlamalar için bir çeşit yasal savunma olarak adlandırılan bir apologia sunar. Bu anlamda apologia, bir pişmanlığı ya da suçluluğu ifade etmez, aksine kişinin masumiyeti üzerine kurgulanır. Suçlamayı yapan kişinin konuşması "logos", bu suçlamalara karşı yanıt veren kişinin savunması ise "apo-logos” olarak adlandırılmıştır. Nitekim Sokrates’in Savunması'nda Sokrates, hâkimlere içinde bulunduğu zor yaşam koşullarının dikkate alınmamasını belirterek, suçlamalara karşı herhangi bir pişmanlık ya da mazeret de bildirmemiştir. ${ }^{4}$ 16. yüzyıla kadar apologia genellikle Antik Yunan'daki bu anlamıyla kullanılmıştır. Pişmanlık ve kişinin sorumluluğunu içeren modern anlamıyla sözcük, 16. yüzyıldan sonra yaygın olarak kullanılmaya başlamıştır.

3 Michael Cunningham, "The Ideological Location of the Apology", Journal of Political Ideologies, Cilt 16, No.1, 2011, s.117.

4 Yosef Z. Liebersohn et.al., "Oh Baby, it's Hard for me to Say I'm Sorry: Public Apologetic Speech and Cultural Rhetorical Resources”, Journal of Pragmatics, Cilt 36, No.5, 2004, s.923. 
Kavramın İngilizce'de, Türkçe'ye her iki şekilde de özür dilemek olarak çevrilebilen iki kullanımı vardır. Bunlardan ilki sorry diğeriyse apology'dir. Ancak bu çalışmada kullanılan özür dilemekten kastedilen şey apology'dir. Çünkü "I am sorry" ve "I apologize" kullanımları içerik olarak birbirinden ayrılmaktadır. İlki sadece kişinin herhangi bir olay ya da eylemdeki üzüntüsünü ifade ederken, ikincisiyse kişinin olay/eylem ya da söylemdeki sorumluluğunu da içermektedir. ${ }^{5} \mathrm{Bu}$ anlamda özür dilemek, sadece meseleye ilişkin sıradan bir pişmanlık bildirme eylemi değil aynı zamanda, kişinin yanlış yaptığının kabulü ve tanınmasını da içerir ki bu kabul, özür dilemeyi üzüntüden ayırır. ${ }^{6}$ Yine özür dilemek, konuya açıklık getirme ya da gerekçelerini açıklama ve son olarak da özrü gerektiren konunun yeniden yapılmayacağını ve ortaya çıkan mağduriyetin giderilmesini veya tazminini de içermektedir. ${ }^{7}$ Bu anlamıyla kullanıldığında özür dilemek, aslında özür dilemeye sebebiyet veren söylem/eylem/uygulamaların adil/meşru olmadığını da kabul etmek demektir. ${ }^{8}$

Sosyal yaşamda bireyler, genellikle üç farklı motivasyon nedeniyle özür dilerler. Birey, öncelikle aslında kendisinin doğrudan sorumluluğu olmayan bir durumdan dolayı pişmanlık belirtmek için özür dileyebilir. İkinci olarak, kişinin ortaya çıkan durumda kasıtlı bir şekilde olmasa da bir sorumluluğu olabilir, bu durumdaki pişmanlığını belirtmek için özür dileyebilir. Üçüncü olarak birey hem sorumluluğunun olduğu hem de kasten yapt1ğ1 eylemler yüzünden pişmanlığını belirtmek için özür dileyebilir. Buradaki üçlü tasnif devletler için de kullanılabilir. ${ }^{9}$ Ancak burada dikkat edilmesi gereken nokta, ilk durumda bireyin doğrudan bir sorumluluğu olmadığg için konuya ilişkin üzüntüsünü göstermek adına özür dilediğidir. Bu anlamda buradaki özür bir apology olmaktan çok bir sorry’ye daha yakındır. ${ }^{10}$ Özrün anlamlı olabilmesi için telafi edici de olması gerekir. Nitekim kişinin sorumluluğu ve özür arasında doğrudan bir ilişkinin olması, özrü (apology) üzüntüden (sorry) ayıran temel kıstaslardan biridir. ${ }^{11}$ Devletler de sosyal yaşamda bireylerin özür konusundaki motivasyonlarıyla paralel şekilde geçmişte yaşanan gelişmeler ya da izlenen bazı politikalar nedeniyle uluslararası ilişkilerde son dönemde yaygın olarak örneklerini gördüğümüz üzere özür dilediklerini belirtmektedirler.

1970'li yıllardan itibaren uluslararası ilişkilerde insan hakları alanında yaşanan gelişmeler, demokratikleşme konusunda atılan adımlar ve kamuoyunun, uluslararası

5 Michael J. A. Wohl et.al., "A Critical Review of Official Public Apologies: Aims, Pitfalls, and a Staircase Model of Effectiveness", Social Issues and Policy Revierw, Cilt 5, No.1, 2011, s.73.

6 Robert R. Weyeneth, "The Power of Apology and the Process of Historical Reconciliation", The Public Historian, Cilt 23, No.3, 2001, s.17.

7 Nicholas Tavuchis, Mea Culpa: A Sociology of Apology and Reconciliation, Stanford, Stanford University Press, 1991, s.vii.

8 Girma Nagesh, Apologia Politica: States E Their Apologies by Proxy, Lanham, Lexington Books, 2006, s.14.

9 Raymond Cohen, "Apology and Reconciliation in International Relations", Yaacov B. S. Tov (der.), From Conflict Resolution to Reconciliation, New York, Oxford University Press, 2004, s.186.

10 Lee Taft, "Apology Subverted: The Commodification of Apology", The Yale Law Journal, Cilt 109, No.5, 2000, s.1140.

11 Michael Cunningham, "Saying Sorry: The Politics of Apology", The Political Quarterly, Cilt 70, No.3, 1999, s.287-288. 
toplumun siyasetin yapımı ve yürütülmesinde giderek etkili bir güç olmaya başlaması, devletlerin hem içlerindeki bir takım gruplara hem de diğer uluslararası yapılara yönelik geçmişteki bazı uygulama ve politikalarını gözden geçirmelerine yol açmıştır. ${ }^{12}$ Kampf da sürecin aslında 1990'lı yıllarda başladığını ve bu dönemden sonra “özür çağg” olarak adlandırabileceğimiz bir döneme geçiş yaptığımızı ileri sürmektedir. Ona göre bu özür çağının başlangıcını tetikleyen dört ana etmen vardır. Birincisi, kiliselerin (Kanada, Macaristan, Katolik Kilisesi gibi örneklerin etkisiyle) başlattığı özür akımı dünya çapında bir trende dönüşmüştür. İkincisi, çok kültürlülüğün etkisi ve farklılıkların tanınmasıyla marjinalize edilmiş, çevrede yer alan, sessiz grupların sesleri duyulmaya başlamış ve bu gruplar geçmişteki yanlışlar için sembolik tazminatlar talep etmişler ve bu durum özür dilemek konusundaki eğilimlerin güç kazanmasına yol açmıştır. Üçüncüsü, kamuya mal olmuş bazı figürler ve politikacılar gibi bireyler tarafından dilenen kişisel özürlerin sayısının artması da siyasi özür konusunda bir zenginliğin ve çeşitliliğin ortaya çıkmasını sağlamıştır. Dördüncüsü, telekomünikasyon ve iletişim teknolojisi alanında yaşanan gelişmeler ve iletişim araçlarının yarattığı baskının etkisiyle örneğin Papa'nın 2000 yılında İsrail'i ziyareti öncesi medyada yer alan "özür dileyecek mi” baskısı gibi tetikleyici unsurlarla bir özür çağına geçiş yapılmıştır. ${ }^{13}$

Kampf'ın sıraladığ 1 bu unsurlara ek olarak Olick, kamuoyundan ve özellikle de elitlerden gelen siyasal baskıların da devletlerin özür dileme sürecinde etkili olduğu gerçeğinin altını çizmektedir. ${ }^{14}$ Cunningham ise, son dönemlerde tecrübe ettiğimiz "özür patlamasının” temelinde, kimlik politikalarının öneminin anlaşılmasının yattığını ileri sürmektedir. ${ }^{15}$ "Özür Çağı" başlığıyla bir çalışma kaleme alan Gibney’e göre ise sosyal hareketlerin güç kazanması, özür konusundaki bireysel taleplerin artış göstermesi, çok kültürlülük bilincinin yerleşmesi ve "öteki”nin siyasal özne olarak kabulü özür sayısındaki artışı doğuran temel etkenlerdir. ${ }^{16}$

Farklı çalışmalarda özür çağının gerekçeleri konusunda farklı unsurlar ön plana çıkarılmış olsa da, son çeyrek asırda siyasi özürlerin sayısının arttığı bir gerçektir. Bu süreç, özür dilemek konusunda devletleri dört farklı seçenekten birini tercih etmeye zorlamıştır. Devletlerin önemli bir bölümü "geçmişle hesaplaşma” olarak adlandırılacak bu sürecin ardından geçmişte yaşanan şeyleri reddederek ve politika ya da söylem olarak herhangi

12 Roy L. Brooks, "The Age of Apology", Roy L. Brooks (der.), When Sorry Isn't Enough: The Controversy over Apologies and Reparations for Human Injustice, New York, New York University Press, 1999, s.3-11.

13 Zohar Kampf, "The Age of Apology: Evidence from the Israeli Public Discourse", Social Semiotics, Cilt 19, No.3, 2009, s.260-261.

14 Jeffrey K. Olick, The Politics of Regret: On Collective Memory and Historical Responsibility, New York, Routledge, 2007, s.140.

15 Michael Cunningham, "It Wasn't Us and We Didn't Benefit: The Discourse of Opposition to an Apology by Britain for its Role in the Slave Trade”, The Political Quarterly, Cilt 79, No.2, 2008, s.252-258.

16 Rhoda E. H. Hassmann ve Mark Gibney, "Introduction: Apologies and the West", Mark Gibney (der.), The Age of Apology: Facing Up to the Past, Pennsylvania, University of Pennsylvania Press, 2008, s.4. 
bir yanlışl1k yapmadıkları sonucuna ulaşmışlardır. Bazı devletlerse geçmişte yaşanan gelişmeleri ve yapılan bir takım yanlışıkları kabul etmekle birlikte, özür dilemeyi gerektirecek bir durumun söz konusu olmadığını dile getirmişlerdir. Yine bazı devletlerse yanlışlıkları ve ortaya çıan mağduriyetleri kabul etmekle birlikte, özür dilemek ve mağduriyetleri gidermek için bazı koşulların oluşması gerektiğini ileri sürerek bir anlamda koşullu özür dilemişlerdir. Son olaraksa bazı devletler de hem geçmişteki yanlışlıkları hem de özür dilemeyi bir şarta bağlamadan kabul etmişlerdir. Bu dört seçenek içinde pişmanlığı ve affedilmeyi içeren ve bu anlamda gerçek anlamda özür olarak kabul edilebilecek tek seçenek sonuncusudur. ${ }^{17}$

Herhangi bir şarta bağlanan ya da yanlışı kabul etmeyen, olaya ilişkin sorumluluğu üstlenmeyen, mağduriyeti ve mağduriyetin giderilmesini içeren teklifleri bünyesinde barındırmayan, doğruyu/gerçeği ortaya çıkarmaya çalışmayan ve benzer uygulamaların yeniden yaşanmayacağı konusunda teminat vermeyen özürler gerçek bir özür olarak kabul edilemez. ${ }^{18}$ Lazare bu tür özürleri "sahte özür" (pseudo apology) olarak tanımlamaktadır. Ona göre, geçmişteki yanlışı ya da hatayı kabul ederken kapalı, belirsiz ifadeler kullanmak, özür dileyenin sorumluluğunu azaltmak adına edilgen filler kullanmak, özrü belirli şartlara bağlamak, ortaya çıkmış zararı ya da bu zararın ciddiyetini sorgulamak, ortadaki suçu/saldırıy/hatayı minimize etmek ya da manipüle ederek asıl olay için değil tali meseleler için özür dilemek, olayın merkezinde yer alan taraflar yerine başka kesimlerden özür dilemek, sahte özür olarak tasnif edilmektedir. ${ }^{19}$ Gerçek bir özür, aslında hem ulusal hem de uluslararası ölçekte geçmişteki bir takım yanlışlıkların düzeltilmesi ve hataların telafi edilmesi noktasında oldukça önemli bir araçtır. ${ }^{20}$ Çünkü özür dilemenin en temel amacı en azından diğer materyal ve hukuki tazmin araçlarından farklı olarak -sembolik düzeyde dahi olsa bile- özrü dileyen ve özür dilenen arasında hataları yapan tarafin affedilmesi ve uzlaşmanın sağlanmasıdır. ${ }^{21}$

Taraflar arasında uzlaşının sağlanabilmesi için özrün gerçek/samimi bir özür olarak formüle edilmesi gerekmektedir. ${ }^{22}$ Macleod özrün nasıl formüle edilmesi gerektiği konusunda altı temel sorunun yanıtlanması gerektiğini belirtmektedir. Öncelikle özür dileyen ve dilenen kimdir? Eğer geçmişteki bazı yanlışlıklarda sorumluluğu olan taraflar

17 Danielle Celermajer, The Sins of the Nation and the Ritual of Apologies, Cambridge, Cambridge University Press, 2009, s.14.

18 Carrie J. Petrucci, "Apology in the Criminal Justice Setting: Evidence for Including Apology as an Additional Component in the Legal System", Behavioral Sciences and the Law, Cilt 20, No.4, 2002, s.341.

19 Aapon Lazare, On Apology, New York, Oxford University Press, 2004, s.86; Darrell Puls, "Where Settlements Cannot Go: Towards a Praxis of Reconciliation in Group Conflicts", http://www. mediate.com/articles/pulsd2.cfm (Erişim Tarihi 05 Ağustos 2014).

20 Jean-Marc Coicaud, "Apology: A Small Yet Important Part of Justice", Japanese Journal of Political Science, Cilt 10, No.1,2009, s.95.

21 Kora Andrieu, "Sorry for the Genocide: How Public Apologies Can Help Promote National Reconciliation”, Millennium: Journal of International Studies, Cilt 38, No.1, 2009, s.5.

22 Jennie Davidow, "Methods for Coding Perspectives on Apology and Reconciliation", Kathleen Malley-Morrison et.al. (der.), International Handbook of Peace and Reconciliation, New York, Springer, 2013, s.297. 
özür diliyorsa, bu özür sorunların çözümünde büyük bir etki yapabilir. İkincisi tam olarak zarara/hataya/yanlışlı̆̆a sebebiyet veren şeyler nelerdir? Dilenen özür, yaşanmış yanlışlıkları tam olarak kapsayacak nitelikte olmalı ve somut bir şekilde bu durum ortaya konulmalıdır. Başka bir ifadeyle geçmişteki yanlışlığa yol açan eylem/söylem/politikanın sadece belirli bir bölümüne vurgu yapıp, geri kalan kısımların üzerini örtmek ya da görmezden gelmek dilenen özrün samimiyetini kusurlu kılar. Üçüncüsü, özür neden dilenir? Özrü dileyen taraf, nedenleri ve gerekçeleri açıkça ortaya koymalı, niçin özür dilediği hakkında açıklayıcı bir gerekçe belirtmelidir. Dördüncüsü, özür ne zaman dilenmelidir? Özür dilemek için uygun zaman nedir? Özrün anlamlı ve sorunların çözümünde etkili olabilmesi için zamanlaması önemlidir. Beşincisi, nerede özür dilenmelidir? Kamu önünde ya da özel olarak mı özür dile getirilmelidir? Sosyal yaşamda bazı durumlarda bireyden kamu önünde özür dilemek, bireyin geçmişte yaşadığı sorunların ifşa edilmesine yol açma ihtimali taşıyorsa özür özel olarak dilenebilir. Ancak devletler arasındaki meselelerde özrün kamuya mal olacak şekilde dile getirilmesi gerekmektedir. ${ }^{23}$ Son olarak da özür nasil dilenmelidir? Özrün dilenmesi sürecinde hangi araçlar kullanılmalıdır? Yazılı veya sözlü olarak mı ifade edilmeli ya da başka araçlar kullanılabilir mi? ${ }^{24}$

Macleod'un özrün formüle edilmesi açısından çizdiği bu çerçeve, özrü tanımlamak ve sahte özür ile gerçeği arasındaki farkı anlamak açısından oldukça yol gösterici olabilir. Ancak bu çerçeveye rağmen özür dilemek konusunda bir standart olduğunu söyleyebilmek pek mümkün değildir. Bu noktadaki soruna işaret eden Gibney ve Roxstrom, nasıl ve hangi yollarla özür dileneceği noktasında devletlerin farklı uygulamaları ya da araçları tercih ettiğini belirterek, bir standart geliştirmeye çalışmıştır. Onlara göre özür dilemenin şöyle standartları olabilir: kamuoyu önünde özür dilenmeli, bir tören düzenlenmeli, açıklayıcı olmalı, finansal yardımı içermeli, adaleti tesis edebilecek bir yön ihtiva etmeli, tutarlı olmalı, affedilme beklentisi olmalı ve ikiyüzlülük içermemelidir. ${ }^{25}$ James, bu standartlara özrün yazılı olarak kayıt altına alınmasının gerekliliğini de eklemektedir. ${ }^{26}$ Macleod'un özrün formüle edilmesi açısından çizdiği çerçeveye ve Gibney ve Roxstrom'un belirledikleri standartlara başka noktaları da eklemek mümkündür. Özür dilemenin boyutları üzerinden hareket ederek, daha kapsamlı bir formülasyon yapılabilir. Bu çerçevede özrün dört temel boyutu vardır.

23 Sandra Harris et.al., "The Pragmatics of Political Apologies”, Discourse E' Society, Cilt 17, No.6, 2006, s.720-722.

24 Leslie H. Macleod, "A Time for Apologies: The Legal and Ethical Implications of Apologies in Civil Cases", Cornwall Public Inquiry, Phase 2 Research and Policy Paper Final Paper, April 12, 2008, s.vi. Ayrica bkz. W. L. Benoit, Accounts, Excuses, and Apologies: A Theory of Image Restoration, Albany, State University of New York Press, 1995.

25 Mark Gibney ve Erik Roxstrom, “The Status of State Apologies”, Human Rights Quarterly, Cilt 23, No.4, 2001, s.927-937.

26 Matt James, "Wrestling with the Past: Apologies, Quasi-Apologies, and Non-Apologies in Canada", Mark Gibney et.al. (der.), The Age of Apology: The West Faces its Own Past, Tokyo, United Nations University Press 2007, s.5. 


\section{Siyasal/Diplomatik Özrün Boyutları}

\section{Materyal/Pratik Boyut}

7 Aralık 1970 tarihinde Batı Almanya Başbakanı Willy Brandt, Varşova Gettosundaki Yahudi Anıtı'nın önünde diz çökerek, Nazilerin İkinci Dünya Savaşı öncesi ve esnasındaki Yahudilere karşı işlediği suçlardan dolayı bir anlamda özür dilemiştir. Brandt, 1972 yilında Kudüs Holocaust Müzesi, Yad Vashem’i ziyaretinde de Zebur 103'ün kefaret ve günahların affını içeren ayetlerini okumuştur. ${ }^{27}$ Her iki durumda da Brandt, aslında bir devletin resmi temsilcisi olarak kendi adına değil temsil ettiği devlet adına özür sözcügünü kullanmadan özür dilemiştir. Bu anlamda özrün materyal boyutu sadece resmi yollardan yazılı veya sözlü olarak içinde özür ifadesi geçen bir deklarasyonda bulunmayı kapsamaz. Özür dilemek olarak kabul edilebilecek her türlü eylem, ifade, doküman, tazminat ya da anıt yaptırmak, anmak gibi davranı̧̧lar da özür olarak tanımlanabilir. Yine tarihsel bazı yanlışlıkların tanınması ve kabul edilmesinde geçmişin çeşitli araçlarla nasıl temsil edildiği de oldukça önemli bir husustur. ${ }^{28}$ Başka bir ifadeyle, bu tanıma ya da kabul gelecek nesillere nasıl aktarılıyor, kolektif hafıza ve toplumsal kültür tarafindan nasıl paylaşılıyor? Bu süreçte o devlette yayınlanan kitaplar, filmler, müzikler, kurulan müzeler de özür dilemenin bir aracı olarak kullanılabilir. ${ }^{29}$

\section{Normatif Boyut}

1990 yılında, Mikhael Gorbaçov, İkinci Dünya Savaşı esnasında savaş tutsağı Polonyalı askerlerin Katin Ormanı'nda katledilmesinden Sovyetler Birliği'ni sorumlu tutarak, bu durumu Stalinizm'in en büyük suçlarından biri olarak tanımlamıştır. 2000 yllında $\mathrm{Ru}-$ andadaki soykırımın altıncı yılı için yapılan anma törenleri esnasında Belçika Başbakanı Guy Verhofstadt, hükümetinin Ruanda'daki soykırımı önlemek konusundaki başarısızlığı nedeniyle Ruanda halkından özür dilemiştir. İkinci Dünya Savaşı'ndan sonra Moğolistan, Macaristan ile diplomatik ilişkileri yeniden kurmak için Macar hükümetine gönderdiğgi memorandumda 13. yüzyılda yaşanmı̧ olan Moğol istilaları nedeniyle Macar halkından özür dilediğini de belirtmiştir. ${ }^{30}$ Örneklerden de anlaşılacağ üzere devletler, geçmişte yaşanan bir takım olaylarla yüzleşerek, sorumluluklarını üstlenerek ve mağdur olan taraflardan af dileyerek uluslararası ilişkilerde konuyla ilişkili bir normun tesisine ya da mevcut normun güçlendirilmesine katkıda bulunmaktadırlar. Her ne kadar birçok çevre tarafından özür dilemek sembolik bir girişim olarak değerlendirilmeye devam etse de, doğru zaman, doğru tutumlar ve doğru şekilde dilenen özürler, siyasal anlamda etki doğurabilecek

27 Hannes Swoboda ve Jan Marinus Wiersma, Politics of the Past: The Use and Abuse of History, PSE, Socialist Group in the European Parliament, 2009, s.61.

28 Jennifer Lind, “Apologies in International Politics”, Security Studies, Cilt 18, No.3, 2009, s.522.

29 Stephanie Lawson ve Seiko Tannaka, "War Memories and Japan's 'Normalization' as an International Actor: A Critical Analysis", European Journal of International Relations, Cilt 17, No.3, 2010, s.408.

30 Swoboda ve Wiersma, Politics of the Past, s.61. 
sonuçlar üretebilir. ${ }^{11}$ Özellikle yapılan eylemlerin ya da izlenen bazı politikaların yanlışlığını kabul etmek ve tanımak ilgili eylem/politikanın benzer örnekleri açısından da aynı taleplerin dile getirilmesine ve böyle bir beklentinin oluşmasına yol açabilir. ${ }^{32}$ Gong'un da ifade ettiği üzere toplumsal hafizada belirli olayları "hatırlama" ve "unutma" aslında bize kim olduğumuzu, ulusal kimliğimizin ne olduğunu gösterir ve geçmişin adına geleceğe yönelik bazı değerlerimizi ve amaçlarımızı şekillendirir. ${ }^{33}$

Kolektif özürler, toplumlar arasındaki ayrımların ortadan kalkması ve hem mevcut hem de gelecek dönemler için toplumlar arasındaki diyalog kültürünün yerleşmesi için uygun bir zeminin oluşması ve bazı ortak değer ve çıkarların paylaşılması açısından ciddi bir potansiyele sahiptir. ${ }^{34}$ Devletlerin geçmişte yapılmış yanlışlıklar nedeniyle özür dilemesi, materyal boyutta her zaman bu yanlışarın tazminini beraberinde getirmese bile normatif olarak gelecekte benzer hataların yapılmayacağı garantisinin de verilmesini içermektedir. ${ }^{35}$ Özür dilemek toplumlar arasında hoşgörü, işbirliği ve barı̧̧ içinde bir arada yaşama kültürünün gelişmesine önemli bir düzeyde katkı yapabilir. ${ }^{36} \mathrm{Bu}$ anlamda soykırım, etnik temizlik ya da tüm insanlığı ilgilendiren bazı olaylar için özür dileyen devletlerin diledikleri özrün anlamlı olabilmesi için özrün sadece olayın tarafları ve mağdurları nezdinde değil uluslararası toplum tarafindan da kabul görmesi önemlidir. ${ }^{37}$

\section{Pragmatik Boyut}

2008 yılında Bingazi'yi ziyareti esnasında İtalya Başbakanı Silvio Berlusconi, faşist dönemi İtalya’nın Libya’daki sömürge sürecini eleştirerek Libya halkından özür dilemiştir. Bu özrün hemen ardından iki ülke arasında yaklaşık beş milyar Dolarlık yatırım antlaşması imzalanmış ve İtalya'ya yasa dışı yollarla göçün önlenmesi konusunda taraflar arasında işbirliği yapılmıştır. ${ }^{38}$ Benzer şekilde Japonya, İkinci Dünya Savaşı süresince Güney Doğu Asya’daki saldırgan politikaları ve sorumlusu olduğu mağduriyetler için özür dilemiştir. Ancak birçok çevre tarafından, dilenen bu özürlerin bölgede Japon pazarını genişletmek

31 John S. Moolakkattu, "Remorse and Forgiveness: A Contemporary Political Discussion", Journal of Social Sciences, Cilt 26, No.1,2011, s.14.

32 Carl D. Schneider, "What It Means to Be Sorry: The Power of Apology in Mediation", Mediation Quarterly, Cilt 17, No.3, 2000, s.266.

33 Gerrit W. Gong, "The Beginning of History: Remembering and Forgetting as Strategic Issues", The Washington Quarterly, Cilt 24, No.2, 2001, s.45-47.

34 Jason A. Edwards, "Apologizing for the Past for a Better Future: Collective Apologies in the United States, Australia, and Canada", Southern Communication Journal, Cilt 75, No.1, 2010, s.58.

35 Nicolaus Mills, “The New Culture of Apology”, Dissent, Cilt 48, No.4, 2001, s.116.

36 Elazar Barkan ve Alexander Karn, "Group Apology as an Ethical Imperative”, Elazar Barkan ve Alexander Karn (der.), Taking Wrongs Seriously: Apologies and Reconciliation, Stanford, Stanford University Press, 2006, s.7; Trudy Govier ve Wilhelm Verwoerd, "The Promise and Pitfalls of Apology”, Journal of Social Philosophy, Cilt 33 No.1, 2002, s.80.

37 Ross Carroll, "The Politics of Culpability: Apology and Forgiveness in International Society", http://www.wiscnetwork.org/ljubljana2008/papers/WISC_2008-184.doc (Erişim Tarihi: 05 Ağustos 2014).

38 Swoboda ve Wiersma, Politics of the Past, s.61. 
amacını güttüğü için dile getirildiği ileri sürmektedir. ${ }^{39} 1950$ 'li yılların ortasında yaklaşık 50 farklı durum nedeniyle özür dileyen Japon liderlerin bu özürlerinin samimiyetleri hala sorgulanmaktadir. ${ }^{40}$

Devletler, uluslararası işbirliği imkânlarını geliştirmek, uluslararası alandaki imaj ve prestijlerini artırmak, devletlerle yaşadıkları sorunları daha az maliyetle çözüme kavuşturmak ya da iki ülke arasındaki ilişkilerde bir normalleşme sağlayabilmek adına özür dilemeyi bir dış politika aracı olarak kullanabilirler. ${ }^{41}$ İtalya ve Japonya örneklerinde de olduğu üzere, devletler özellikle siyasal geçiş ve değişim sürecini tecrübe ederken hem ahlaki hem de sosyal mirasları olan bazı tarihsel hatalardan kurtulmak adına özür dileme yolunu tercih edebilmektedirler. ${ }^{42}$

\section{Hukuki/Yasal Boyut}

7 Mayıs 1999 tarihinde NATO'nun Kosova'ya müdahalesi esnasında ABD ordusuna ait B2 uçakları "yanlışlıkla" Belgrad'daki Çin Halk Cumhuriyeti (ÇHC) Büyükelçiliği'ni bombalamış ve olayda 4 ÇHC vatandaşı hayatını kaybederken 20 kişi de yaralanmışıtır. Bombalamanın ardından 9 Mayıs'ta ABD Başkanı Bill Clinton, ÇHC Başbakanı'na gönderdiği resmi yazıyla ne kadar üzgün olduğunu belirtmiş, 10 Mayıs'ta da kamuoyu önünde üzgün olduğunu ve özür dilediğini ifade etmiştir. Clinton’un 10 Mayıs günü takım elbiseli olmadan günlük kıyafetleriyle özür dilemesi, sözlerinin kişisel ve o anlık olduğuyla ilgili eleştirilere yol açmışır. ${ }^{43}$ Hatta ÇHC basın organları Clinton'un özrünü gerçek bir özür olmadığ 1 gerekçesiyle yayınlamaya dahi gerek görmemişlerdir. ${ }^{44}$ Bir ay sonra ABD, olay nedeniyle 4,5 milyon Dolar tazminat ödeyeceğini ancak bunun yasal bir sorumluluk olarak anlaşılmamasını ve daha başka bir özrün de dile getirilmeyeceğini belirtmiştir. ${ }^{45}$

Özür dilemek, aynı zamanda konuya ilişkin sorumluluğu da kabul etmek demektir. Özür dilenmesine sebebiyet veren durumun niteliğine bağlı olarak ortaya çıkan zarar/ mağduriyetin de giderilmesi gerekmektedir. Eğer devlet, hem sorumluluğunu kabul edip hem de mağduriyeti gidermeye yönelik bir takım araçları devreye sokuyorsa, özrün gerçekliği, samimiyeti ve geçerliliği konusundaki şüpheler de ortadan kalkmaktadır. ${ }^{46}$ Devletlerin özür dilerken özrün yasal boyutunda konunun bir uluslararası mahkemeye ya da özel

39 Lind, “Apologies", s.524.

40 Renee Jeffery, "When is an Apology not an Apology? Contrition Chic and Japan's (un) Apologetic Politics", Australian Journal of International Affairs, Cilt 65, No.5, 2011, s.608.

41 Jason A. Edwards, "The Mission of Healing: Kofi Annan's Failed Apology", Atlantic Journal of Communication, Cilt 16, No.2, 2008, s.88-104.

42 Ernesto Verdeja, "Official Apologies in the Aftermath of Political Violence", Metaphilosophy, Cilt 41, No.4, 2010, s.564.

43 Cohen, "Apology and Reconciliation", s.191.

44 Linda Stamato, "Peace and the Culture and Politics of Apology", Peace Review: A Journal of Social Justice, Cilt 20, No.3, 2008, s.393.

45 Cohen, "Apology and Reconciliation", s.191.

46 Michael Cunningham, "Prisoners of the Japanese and the Politics of Apology: A Battle over History and Memory", Journal of Contemporary History, Cilt 39, No.4, 2004, s.573. 
olarak tesis edilecek bir mahkemeye taşınması, konuyla ilgili bir komisyonun kurulması, doğrudan sorumluluğu olanların yargılanması, tazminat ödenmesi ve hatta toprak kazanımlarının geri iadesi de dâhil olmak üzere bir takım araçlar kullanılabilir. Özür dilemek, geçmişte yapılmış bir takım yanlışlıkların giderilmesi noktasında oldukça önemli bir işleve sahiptir ve fakat en önemlisi yanlış yapanın cezalandırılmasıdır. ${ }^{47}$

Özür dilemenin hukuki boyutu konusunda en kapsamlı çalışmayı yapan Bilder'e göre özür dileyen devlet, uluslararası hukuk çerçevesinde yanlı̧̧ yaptığını kabul etmektedir ki bu özür, uluslararası teamül hukukunu doğrudan etkilemektedir. ${ }^{48}$ Ona göre birçok ulusal hukuk sisteminin aksine uluslararası hukuk devletlerin dilediği özrü uluslararası hukukun ihlalinin resmi yollardan telafisi olarak kabul etmektedir. Ancak özür dilemenin bu önemine rağmen Bilder, özür dilemenin, zararı karşılama ya da tazmin etme gibi rollerde de olduğu üzere genellikle istisnai ya da destekleyici bir ihtiva içerdiği vurgusunu da eklemektedir. ${ }^{49}$ Özrün uluslararası ilişkilerdeki yaşanan bazı haksızlıkların çözümündeki rolü, BM Uluslararası Hukuk Komisyonu'nun 2001 yılında tamamlayarak BM Genel Kurulu'na gönderdiği Uluslararası Yasadışı Fiillerde Devletlerin Sorumluluğuna İlişkin Taslak'ta (Responsibility of States for Internationally Wrongful Acts) ele alınmıştır. ${ }^{50} 59$ madde ve dört ana bölümden oluşan Taslağın devletlerin uluslararası sorumluluğunun içeriği başlıklı ikinci bölümündeki 37. madde, "eğer devletin sebep olduğu herhangi bir zararın karşılanması ve telafisi mümkün değilse, devlet hukuka aykırılık teşkil eden eylemi kabul eden, pişmanlık içeren resmi bir özür dilemelidir” ilkesini düzenlemektedir. ${ }^{51}$ BM Uluslararası Hukuk Komisyonu'nun bu çalı̧̧ması taslak niteliğinde olsa dahi, özrün hukuki olarak bir anlam ifade etmesi açısından oldukça önemli bir gelişmedir.

Özrün yasal boyutunda yaşanan gelişmeler, özür çağı söyleminin yaygınlaşması ve devletlerin son dönemde giderek daha çok özür diliyor olmasının özellikle devletler açısından yarattığı bazı potansiyel "tehditleri” vurgulayan Gerçekçi yorumlar da dile getirilmektedir. ${ }^{52}$ Watts'a göre, uluslararası ilişkilerde özür dilemek, diplomatik olarak övgüye mazhar ancak hukuki olarak tehlikelidir. Özür dilemek günlük yaşamda olduğu gibi uluslararası politikada da bazı talihsiz durumların çözümünde önemli bir rol oynar ve fakat beraberinde hukuki bir sorumluluk da getirmektedir. Burada özrü dileyen devlet açısından

47 Roman David ve Susanne Y. P. Choi, "Forgiveness and Transitional Justice in the Czech Republic", The Journal of Conflict Resolution, Cilt 50, No.3, 2006, s.361-362.

48 Richard B. Bilder, “The Role of Apology in International Law”, Virginia Journal of International Law, Cilt 46, No 3, 2006, s. 459.

49 Richard B. Bilder, “The Role of Apology in International Law”, Mark Gibney (der.), The Age of Apology: Facing Up to the Past, Pennsylvania, University of Pennsylvania Press, 2008, s.19.

50 James Crawford, "Articles on Responsibility of States for Internationally Wrongful Acts", http://legal.un.org/avl/pdf/ha/rsiwa/rsiwa_e.pdf (Erişim Tarihi: 23 Temmuz 2014).

51 Draft articles on Responsibility of States for Internationally Wrongful Acts Adopted by the International Law Commission at its Fifty-Third Session (2001), http://www.ilsa.org/jessup/ jessup06/basicmats2/DASR.pdf (Erişim Tarihi: 01 Ağustos 2014).

52 Janna Thompson, "Apology, Justice and Respect: A Critical Defence of Political Apology", Australian Association for Professional and Applied Ethics 12th Annual Conference, Adelaide, 28-30 Eylül 2005, s.6. 
asıl mesele, diplomatik olarak kazanç sağlamak ancak hukuki risklerden de kurtulmak ve hukuki kazancın diplomatik başarıya mani olmasına engel olmaktır ki Watts bu işi özrün sanatı olarak tanımlar. ${ }^{53}$ Watts'un sanat olarak tanımladı̆̆ı şey ne gerçek özrün tanımıyla ne de özrün hukuki boyutuyla bağdaşmasa da devletlerin birçok olayda aynı motivasyonla özür dilediklerine sıklıkla rastlamaktayız.

\section{Devletler Niçin Özür Diler? Özrün Kuramı}

Uluslararası ilişkilerde son dönemdeki özür çağı, siyasal anlamda Gerçekçi temayüle sahip ve hukuki anlamda da ihtiyatlı yaklaşan çevreler dişındaki akademik dünyada büyük oranda kabul görmekte ve desteklenmektedir. Sorunların çözümünde daha barışç1l ve diyalogu mümkün kılan bir yol içerdiği için özür dilemek, devletler açısından siyasal olarak da stratejik bir değer ihtiva etmektedir. Uluslararası İlişkiler çalışmalarının yaklaşık bir asırlik tarihinde bir analiz parametresi olarak yeterli düzeyde ilgi göremese de özür dilemek küresel politikada artık bir araç olarak sıklıkla kullanılmaktadır. ${ }^{54} \mathrm{Bu}$ durumun bir göstergesi olarak MacLachlan sadece son 10 yıllık dönemde 50'den fazla resmi özrün devletler ve diğer aktörler tarafından dilendiğini not etmektedir. ${ }^{55}$ Aslında özür dilemek, tarihsel süreçte devletlerin neden oldukları bazı yanlışlıkların giderilmesi noktasında kullanılan bir araç olarak ortaya çıkmıştır. Devletler aynen sosyal yaşamdaki bireyler gibi, hatalarını kabul ederek, hatadaki sorumluluklarını tanıyarak, ortaya çıkan durumdan dolayı pişmanlıklarını bildirerek ve benzer yanlışlıkların yeniden yapılmayacağı konusunda taahhütte bulunarak özür dilemektedirler. ${ }^{56}$

Peki, devletler neden ve hangi gerekçelerle özür diler? Son dönemde tecrübe ettiğimiz bu "özür çağı" uluslararası ilişkiler algımız ve tanımlarımızı nasıl ve hangi açılardan etkilemektedir? Uluslararası İlişkilerdeki hâkim Pozitivist temayül, temel karakteristiği anarşi olan uluslararası ilişkilerde devleti hayatta kalma (survival) mücadelesi içinde kendi çıkarını ve gücünü maksimize etmeye çalı̧̧an rasyonel bir yapı olarak tanımlamıştır. Bu anlamda devlet zamandan ve mekândan münezzeh, dünyanın her bölgesi için geçerli, evrensel ve tek bir form gibi yansıtılmıştır. ${ }^{57}$ Ancak özür dilemek, aynen teşekkür etmek ya da şikâyet etmek gibi bir eylemin/olayın sonrasında ortaya çıkan durumlar için kullanılır. Her şeye hazır ve nazır, "hikmetinden sual edilmez" ve kadiri mutlakın bir yansıması olan devletin hatasını/yanlışlığını kabul edip, pişmanlık ve sorumluğunu tanıması devletin rasyonalitesiyle ilgili tezlerin gözden geçirilmesine işaret eder. Bununla birlikte daha önce

53 Arthur Watts, “The Art of Apology”, Maurizio Ragazzi (der.), International Responsibility Today: Essays in Memory of Oscar Schachter, Leiden, Martinus Nijhoff Publishers, 2005, s.116.

54 Judith Renner, "I'm Sorry for Apologising': Czech and German Apologies and their Perlocutionary Effects", Review of International Studies, Cilt 37, No.4, 2011, s.1583.

55 Alice MacLachlan, “The State of "Sorry": Official Apologies and their Absence", Journal of Human Rights, Cilt 9, No.3, 2010, s.373.

56 Michael R. Marrus, "Official Apologies and the Quest for Historical Justice”, Journal of Human Rights, Cilt 6, No. 1, 2007, s.75-79.

57 Erdem Özlük, Uluslararası İlişkilerde Devlet: Tanım, Teori ve Devlet İstisnacıliğı, Konya, Çizgi, 2012, s.168. 
de belirtildiği üzere pragmatik gerekçelerle de devletlerin Pozitivist algıdaki rasyonalite söylemine uygun düşecek şekilde özür dileyebileceğini de not etmek gerekmektedir.

Bilder, devletlerin hangi motivasyonlarla ve neden özür diledikleri konusunda sekiz seçenek sıralamaktadır. Ona göre devlet, her şeyden önce belirli bir durumla ilgili olarak özür dilemenin doğru olduğunu düşündüğü için özür diler. Özür dilemenin prestij ve uluslararası toplum nezdinde devletin imajı açısından bir değer kazandıracağına ilişkin inanç beslediği için özür diler. Uluslararası hukuk, örgüt ya da bir mahkemenin bu devletin ilgili olayda özür dilemesine yönelik bağlayıcı bir kararı olduğu için özür diler. Devlet, özellikle özrün normatif boyutunda da belirtildiği üzere, nadiren de olsa, uluslararası teamül hukukuna ve antlaşmaların yorumuna katkı yapmak için özür diler. Yine rasyonel olarak fayda maliyet analizi sonucunda karşılaştı̆̆ 1 bir sorunun büyümesini engellemek ve çözüm üretmek için özür diler. 1937 yılında Japonların Çin’in Yangtze Nehri'ndeki ABD gemisini (Panay Olayı olarak bilinen hadise) "yanlışlıkla” batırarak, özür dilemesi örneğinde olduğu üzere devletler bir taktik olarak özrü kullanabilir; kasıtlı olarak eylemi gerçekleştirip arkasından hemen özür dilemeyi seçebilirler. Devletler bazen politika yapım sürecinde önünde başkaca bir seçenek olmadığ $1 /$ kalmadığı durumlarda özür diler. Son olarak da bir çeşit halkla ilişkiler çalışması ve kamuoyu desteğini kazanmak için özür diler. ${ }^{58}$

Devletler, Bilder'in oldukça kapsamlı bu seçenekler dizisinin dışında başka bir takım gerekçelerle de özür dilemektedirler. Deborah Levi, devletlerin özür dileyerek, özür dilenmesi gereken tarafin güvenini kazanarak, onu etkilemek ve bu anlamda etki alanını genişletmek için de özür dileyebileceğini eklemektedir. Böylelikle konuyla ilişkili herhangi bir sorunda devlet pazarlık gücünü artırmak isteyebilir. ${ }^{59}$ Gibney ve Roxstrom ise, aynen Bilder gibi özür dilemenin uluslararası hukuka teamül açıdan ciddi bir katkı yapacağını belirterek, devletin özür dilemesinin onun dış politikasının değişmiş olduğunu göstermesi açısından da önemli olduğunun altını çizmektedir. ${ }^{60} \mathrm{Bu}$ değişimin doğal bir uzantısı olarak özür dileyen devletler diğer devletlerle yaşadıkları sorunlarda, sadece geçmişte yapılan bazı hatalara ilişkin değil diğer alanlarda da, uzlaşıya açık oldukları mesajını vermektedirler. ${ }^{61}$ Nitekim özür dilemek, o devletten kaynaklanan bazı tehdit algılarının azalmasına katkıda bulunabilir. Çünkü özür dileyen devlet, kuvvet kullanma da dâhil olmak üzere zorlayıcı ya da saldırgan girişimlerde bulunmayacağını hem kendi kamuoyuna hem de uluslararası topluma bir anlamda deklare etmektedir. ${ }^{62}$

Özür dilemek ve algılanan tehdit arasındaki bağlantıyı tarihsel olarak Almanya ve Japonya örnekleri üzerinden değerlendiren ve bu durumu “özür kuramı" (apology theory)

58 Bilder, "The Role of Apology in International Law", s.462-466.

59 Deborah L. Levi, "The Role of Apology in Mediation”, New York University Law Review, Cilt 72, No.5, 1997, s.1166.

60 Gibney ve Roxstrom, “The Status of State Apologies”, s.915.

61 Marguerite La Caze, "The Asymmetry between Apology and Forgiveness", Contemporary Political Theory, Cilt 5, No.4, 2006, s.448.

62 Jennifer Lind, "Sorry States: Apologies in International Politics", APSA Meeting, Washington, D.C., 1-4 Eylül 2005. 
olarak adlandıran Lind'e göre, Almanya’nın Nazi dönemindeki bir takım politikaların sonucu olan gelişmelerden dolayı özür dilemesi, Almanya kaynaklı tehditlerin ciddi oranda azalmasına yol açmıştır. Ancak Japonya ise geçmişiyle ilgili sürekli olarak müphem özürler dilediği için özellikle komşu ülkelerin hala Japonya'dan bir tehdit hissettiklerini de ileri sürmektedir. ${ }^{63}$ Nitekim Lawson ve Tannaka da, Lind'in bu tezini destekleyerek, Nisan 2005 tarihinde dönemin Japonya Başbakanı Koizumi’nin Asya-Afrika zirvesinde yaptı̆̆1 bir konuşmayı işaret etmektedir. Koizumi, Japonya’nın tarihsel olarak Asya'daki saldırgan tavırları nedeniyle derin bir pişmanlık duyduğunu belirterek, özür dilemiştir. Ancak konuşması esnasında özrün Japonca karşllığ olan shazai yerine, üzüntü duymak olarak çevrilebilecek owabi sözcüğünü kullanmayı tercih etmiştir. ${ }^{64} \mathrm{Lind}$, geçmişte yapılmış olan bazı hataları reddetmenin taraflar arasındaki uzlaşmayı olumsuz açıdan etkilediğini ve Çin, Kore ve Japonya arasındaki ilişkilerde Japonya'nın müphem özürleri nedeniyle tam olarak uzlaşma sağlanamadığını belirtmektedir. ${ }^{65}$ Çünkü bazı tarihsel hatalar ya da suçların sorumluluğu kabul edilmediği ve gerçek bir özür dilenmediği sürece, taraflar arasında bir diyalog zemininin oluşma ihtimali oldukça düşüktür. ${ }^{66}$ Lind'in özrün kuramı dediği şeye Nobles "özür politikası" (apology politics) adını vermekte ve geçmişte yapılan yanlışlıkları sadece reddetmiş olmanın yeterli olmadığını aynı zamanda konuya ilişkin gerçek bir özrün de dile getirilmesini istikrarlı bir ilişki için gerekli görmektedir. ${ }^{67}$

Devletlerin özür dilemesi konuyla ilişkili toplumsal hafızanın her iki tarafta da yeniden canlanmasına ya da yoğunlaşmasına yol açar. Özellikle özür dileyen taraf aç1sından suçluluk, sorumluluk ve hatta utanç duygusu gibi duyguların yoğunlaşma ihtimali devletlerin özür dilemek konusunda daha muhafazakâr bir duruş sergilemelerini de beraberinde getirmektedir. Çünkü devletler, kuvvet kullanma ve şiddet içeren bazı politikalar da dâhil olmak üzere geçmişte yaptıkları eylemler nedeniyle geçmişin kutsanmas1 ve görkemi konusunda yüksek bir beceriye sahiptir. Geçmişi meşrulaştırmak, hataları unutmak ya da reddetmek, ahlaki olarak sorgulanmasını önlemek devletlerin çok sık başvurdukları alışkanlıklardır. ${ }^{68}$ Devletlerin özür dilemek konusundaki muhafazakâr tavrını değiştirebilecek en temel güçlerden biri hem ulusal hem de uluslararası kamuoyu tarafından yapılacak baskıdır. Toplumsal anlamda devletin özür dilemesi konusunda

63 Jennifer Lind, "Apologies and Threat Reduction in Postwar Europe", Memory of Violence Workshop, Massachusetts Institute of Technology, 24-25 Ocak 2003.

64 Lawson ve Tannaka, "War Memories and", s.420.

65 Lind, "Apologies", s.518-522. Benzer tespitler için bkz. Katja Hanke et.al., "When the Past Haunts the Present: Intergroup Forgiveness and Historical Closure in Post-World War II Societies in Asia and in Europe", International Journal of Intercultural Relations, Cilt 37, No.3, 2013, s.288.

66 Lily Gardner Feldman, "The Principle and Practice of 'Reconciliation' in German Foreign Policy: Relations with France, Israel, Poland and the Czech Republic”, International Affairs, Cilt 75, No.2, 1999, s.335.

67 Melissa Nobles, The Politics of Official Apologies, Cambridge, Cambridge University Press, 2008, s.154.

68 Darío Páez, "Official or Political Apologies and Improvement of Intergroup Relations: A NeoDurkheimian Approach to Official Apologies as Rituals”, Revista de Psicología Social, Cilt 25, No.1, 2010, s.102. 
oluşacak bir talep, özrü kolaylaştırabilir. ${ }^{69}$ Nitekim son dönemdeki özür çağ́ olarak adlandırılabilecek kadar çok özrün dile getirilmesinin altında yatan ana neden toplumsal taleplerin yoğunlaşmı̧̧ olmasıdır. ${ }^{70}$

Kampf ve Löwenheim, devletlerin neden özür dilediği konusunu, İsrail örneği üzerinden “özrün ritüelleri” olarak adlandırdıkları üç faktörle açıklamıştır. İlk olarak, özür devletler için bir çeşit arınma ritüelinin bir parçasıdır. 2000 yılında Vatikan'ın İsrail'den Yahudilere karşı tarihsel olarak yapılmış hatalar nedeniyle özür dilemesi bu arınmanın bir örneğidir. Özür dileyen taraf, geçmişteki hatadan özür yoluyla arınarak, yeni ve daha olumlu bir imaja sahip olmaktadır. ${ }^{71}$ İkincisi devletler yapmış oldukları bazı uygulamalardan dolayı kasıtlı olmadan diğer devletleri aşağılamış ya da küçük düşürmüş olabilirler; karşı taraf aşağılandığıyla ilgili bir algıya sahip olabilir. Devlet, aslında yaptığında herhangi bir yanlışlık olduğuna inanmasa da, karşı tarafın aşağılandığına ilişkin bir algıya sahip olması nedeniyle özür dileyebilir. Taraflardan birinin küçük düşürüldüğüne inandığg bir ortamda, devletler arasında sağlıklı bir iletişimin kurulması kolay olmayacaktır. Bu nedenle devlet, özür dileyebilir. 2001 yılında Hainan Adası olayında ABD casus uçağının ÇHC uçağıyla çarpışması sonucunda ABD'nin ÇHC'den; 2007 yılında İran karasularına 15 İngiliz deniz piyadesinin izinsiz olarak girmesi nedeniyle İngiltere İran'dan; Muammer Kaddafi'nin oğlunu 2009 yılında ülkeyi ziyareti esnasında tutuklayan İsviçre Libya'dan; 2010 yılında İsrail Dışişleri Bakanı Danny Ayalon’un “alçak koltuk krizi” nedeniyle Türkiye'den özür dilemesi bu duruma örnek olarak verilebilir. ${ }^{72}$ Arınma ve küçük düşürme ritüellerinin bir sonucu olarak özür dilemede tek taraflı bir girişim söz konusuyken üçüncü ritüel olan uzlaşma ritüeli karşılıklı bir işbirliğine dayanmaktadır. Her iki tarafın da üzerinde anlaşabilecekleri ortak bir zemin üzerinde buluşarak uzlaşmaları beraberinde özür dilemeyi getirebilir. Kampf ve Löwenheim uzlaşma ritüeline örnek olarak, Ürdün Kralı Hüseyin’in 13 Mart 1997 tarihinde Ürdünlü bir askerin İsrailli çocukların okul gezisi esnasında açtıkları ateş sonucunda 7 çocuğun ölmesi üzerine özür dilemesini vermektedir. Kral Hüseyin ölen çocukların ailelerini tek tek ziyaret etmiş ve medya önünde onlardan af dilemiştir. Kral, bu özrüyle İsrail kamuoyunda güven kazanarak, İsrail ile olan ilişkilerini normalleştirmeyi amaçlamıştır. Yine 1997 yılında Almanya ve Çek Cumhuriyeti karşılıklı olarak birbirlerinden özür dilemiştir; Almanya Südetler bölgesini işgali ve Nazi suçları için, Çekler de Südetler Bölgesi’nde yaşayan Almanları sürgün ettikleri için özür dilemiştir. Bu özürler, taraflar arasında uzlaşı ve normalleşme sürecini hızlandırmıştır. ${ }^{73}$

69 Mathias Thaler, "Just Pretending: Political Apologies for Historical Injustice and Vice's Tribute to Virtue", Critical Review of International Social and Political Philosophy, Cilt 15, No.3, 2012, s.260.

70 Zohar Kampf, "Public (non) Apologies: The Discourse of Minimizing Responsibility", Journal of Pragmatics, Cilt 41, No.11, 2009, s.2258; Graham G. Doods, "Governmental Apologies and Political Reconciliation”, Bruno Charbonneau ve Genevieve Parent (der.), Peacebuilding, Memory and Reconciliation: Bridging Top-Down and Bottom-Up Approaches, New York, Routledge, 2012, s.132.

71 Zohar Kampf ve Nava Löwenheim, "Rituals of Apology in the Global Arena", Security Dialogue, Cilt 43, No.1, 2012, s.48.

72 Kampf ve Löwenheim, "Rituals of Apology", s.50.

73 Ibid., s.52. 
Devletler, Kampf ve Löwenheim'ın da işaret ettiği üzere, tarihsel olarak yaptıkları yanlı̧ılıkların giderilmesi noktasında bir arınma stratejisi olarak özrü kullanmaktadırlar. Özellikle liberal demokrasilerin özrü bir çeşit hesap verme ya da şeffaflık aracı olarak değerlendirip, tarihsel tartışmalardan sıyrılarak daha demokratik ve arınmış bir geçmişe sahip olmak için kullandıkları çok fazla örnek mevcuttur. ${ }^{74}$ Bu özürler sadece devletin imajı ya da prestiji açısından veya ilgili ülkeyle ilişkilerini normalleştirmek gibi pragmatik dürtülerle dile getirilmez, ayrıca devletin kendi halkına hesap verebilmesi açısından da işlev taşımaktadır. ${ }^{75}$ Üstelik özür dilemeye esas teşkil eden meselenin günümüzle hiçbir bağlantısı olmasa dahi devletler yine de özür dilemeyi tercih edebilirler. Nitekim Verdaja, özür dileyerek devletlerin kendi tarihlerini aslında eleştirel bir okumaya tabi tuttuklarını, özür dilemeye esas teşkil eden konunun toplumsal ölçekte yeniden tartı̧ılmasını sağladıklarını ve devlet ve toplum arasındaki ilişkilerin yeniden düzenlenmesini sağladığını ileri sürmektedir. ${ }^{76}$ Zaten özür dilemenin en önemli işlevlerinden biri de, özrü dileyen devlet açısından o toplumda tabu olarak değerlendirilen bazı konuların tartı̧̧maya açılmasını sağlamaktır. Aynı zamanda özür dilemek, devletin ilgili konuyu ele aldığını, tartıştığını ve çözüm üretmeye çalıştı̆̆ını göstermesi açısından da önemli bir işlev görmektedir. ${ }^{77}$

Devletlerin neden ve hangi gerekçelerle özür dilediğine ilişkin buraya kadar yapılan tartışmalara birkaç hususu daha eklemek mümkündür. Örneğin devletler, pragmatik olarak, diasporada yaşayan topluluklar üzerinden siyasi bir rant elde edebilmek, o toplulukların ilgili ülkedeki etkinliğinden faydalanabilmek adına da özür dileyebilirler. ${ }^{78}$ Yine özür dilemek uluslararası ilişkilerde devletler arasında patlak veren bir takım uyuşmazlıkların ya da sorunların çözümünde yaygın şekilde başvurulan yöntemlerin dışında bir alternatif olarak çatışma yönetiminin araçlarından biri olarak da kullanılabilir. ${ }^{79}$

\section{Özür Dilemeye Yönelik Eleştiriler}

Son çeyrek asırda diplomatik özürlerin sayısındaki artış, farklı kesimlerce özür taleplerinin giderek daha çok dile getirilmiş olması, konuyla ilgili yapılan tartışmaların hem siyasetçiler tarafından hem de akademik dünyada daha çok ele alınması, kısacası tecrübe

74 Michael Murphy, "Apology, Recognition, and Reconciliation”, Human Rights Review, Cilt 12, No.1, 2011, s.55.

75 Rhoda Howard-Hassmann, “Official Apologies”, Transitional Justice Review, Cilt 1, No.1,2012, s.35-37.

76 Verdeja, “Official Apologies”, s.569-570.

77 Ridwan Nytagodien ve Arthur Neal, "Collective Trauma, Apologies, and the Politics of Memory", Journal of Human Rights, Cilt 3, No.4, 2004, s.471.

78 Alia Somani, "The Apology and its Aftermath: National Atonement or the Management of Minorities?”, Postcolonial Text, Cilt 6, No.1, 2011, s.1.

79 Elazar Barkan, The Guilt of Nations: Restitution and Negotiating Historical Injustices, Baltimore, John Hopkins University Press, 2000, s.322; Alexander Hirsch, "Agony of Reconciliation", Alexander Hirsch (der.), Theorizing Post-Conflict Reconciliation: Agonism, Restitution E Repair, New York, Routledge, 2012, s.3. 
ettiğimiz özür çağı, özür dilemekle ilgili bazı eleştirileri de beraberinde getirmiştir. Özür çağı söyleminin abartılı olduğuna, durumun aslında bir yanılsamadan ibaret olduğuna ilişkin iddialar, daha çok Gerçekçi bakışla özür dilemenin devletler açısından birçok noktada sakıncalı olacağıyla ilgili argümanlar, hukuksal olarak özür dilemenin pratik bir geçerliliği ve değeri olmadığı konusundaki tezler eleştirilerin ana çerçevesini oluşturmaktadır. Literatürde yapılan tüm tartışmaları göz önünde bulundurarak, bu eleştirileri özür dileyen tarafla ilgili yapılan eleştiriler, özrün kendisi, anlamı ve geçerliliğiyle ilgili eleştiriler ve son olarak da özür dilenen tarafla ilgili eleştiriler olmak üzere üç ana grupta toplamak mümkündür.

1998 yılında Afrika ülkelerini ziyareti esnasında ABD Başkanı Bill Clinton, Ruanda'daki trajediyi önlemek konusunda uluslararası toplumun gerekli sorumluluğu gösteremediğini, mülteci kamplarını yeterince koruyamadıklarını ve trajedinin daha büyümesine yol açtıklarını belirterek özür dilemiştir. Aynı ziyaret kapsamında Uganda'da bulunduğu sırada da ABD'nin Afrika ülkelerine karşı her zaman doğru politikalar izleyemediğini ve tarihsel olarak Avrupalı Amerikalıların köle ticaretinden büyük kazançlar elde ettiğini dile getirerek Uganda halkından özür dilemiştir. ${ }^{80}$ Clinton'un bu özürleri üzerinden hareket ederek, bir devlet tarihsel olarak parçası olduğu bir yanlışlık nedeniyle bütün uluslararas1 toplum adına özür dileyebilir mi? Ya da Uganda örneğinde olduğu üzere asırlar önce yapılmış birtakım hatalar nedeniyle özür dileyebilir mi? Bu soruları soran Smith'e göre ABD bütün uluslararası toplumun adına özür dileyebilecek bir yetkiyle donanmadığı için sadece kendi parçası olduğu sorumluluk için özür dilemelidir. ${ }^{81} \mathrm{Bu}$ anlamda özrün anlamlı ve muteber olması için kimin tarafından dile getirildiği önemlidir.

Bir devlet adamı, kendi devleti adına, Uganda örneğinde olduğu üzere, asırlar önce işlenmiş bir suç ya da yanlıştan dolayı özür dileyebilir mi? Joyce, devletin özür dileyebileceğini savunmaktadır. 15. yüzyılda Yahudilerin Portekiz'den sürülmesi konusunda 1988 yılında Portekiz Cumhurbaşkanı Mario Soares, Yahudilerden özür dilemiştir. Joyce’a göre cumhurbaşkanı halkın desteğiyle seçildiği ve onların meşru temsilcisi olduğu için asırlar önce yapılan yanlışlıklar için de özür dilenebilir. ${ }^{82}$ Cunningham ise bir devlet adamının kendisinin değil de öncüllerinin sorumlu olduğu bir hatadan dolayı özür dilemesinin anlamlı olmadığını dile getirmektedir. ${ }^{83}$ Yine başka bir çalışmasında Cunningham, İngiltere'nin köle ticaretinden dolayı özür dilemesi meselesini ele alarak, şu anki insanlar köle ticaretinin tarihsel olarak yarattığı ekonomik zenginlik mirasından pay aldıkları için sorumlu olmadıklarını iddia edemez diyerek, daha önceki teziyle çelişmektedir. Ona göre, günümüzdeki İngilizler, doğrudan kendilerinin olayda bir sorumlulukları olmadığını ileri sürerek özür dilemenin anlamsız olduğuna inanmaktadırlar. Ayrıca kimden özür dilenmesi gerektiği konusundaki belirsizlik, olayın çok uzun bir süre önce yaşanmış olması nedeniyle ortaya çıkan zaman sorunu, geçmişin temsili noktasında İngiliz imajında ya-

80 Emily Mitchel, “Apologies: Who's Sorry Now?”, Index on Censorship, Cilt 27, No.3, 1998, s.47.

81 Nick Smith, I Was Wrong: The Meanings of Apologies, Cambridge, Cambridge University Press, 2008, s.162.

82 Richard Joyce, “Apologizing”, Public Affairs Quarterly, Cilt 13, No.2, 1999, s.159.

83 Cunningham, "Saying Sorry", s.287-288. 
ratabileceği olumsuz etkiler, köle ticaretinin sadece İngilizlere mal edilemeyeceği, o dönemdeki bütün Avrupalı güçlerin bu işte paylarının olduğu ve son olarak da köle ticareti meselesinden daha önemli konuların olduğuna ilişkin tezler özür konusundaki taleplere getirilen temel eleştirilerdir. ${ }^{84}$

Özür dilemek konusunda eleştirel yaklaşan çevreler aynı zamanda özür dilemenin hem taraflar hem de özür dileyen devlet açısından oluşturabileceği bazı hassasiyetlere de işaret etmektedirler. Renner, özür dilemenin çoğu zaman beklendiği gibi taraflar arasında bir uzlaşı yaratamayabileceğini ve hatta konuya ilişkin fikir ayrıllklarını pekiştirme ihtimalinin olduğunu ileri sürmektedir. ${ }^{85}$ Glaser ise, dilenen özrün toplumdaki potansiyel etkileri üzerinde durmaktadır. Ona göre bazı konularda dilenecek özürler, toplumda kutuplaşmaya yol açarak, geçmişe ait bir takım düşmanlık ve nefret hislerinin yeniden yeşermesini sağlayabilir. ${ }^{86}$ Aynı şekilde Lind de, devletin kendi geçmişiyle ilişkili bir olay nedeniyle özür dilemesinin bazı durumlarda toplumsal bir tepkiyle karşılanacağını ve hatta geçmişi inkâra ve geçmişin görkemine ilişkin eğilimlerin toplumda yeniden güç kazanabileceğine işaret etmektedir. Böyle bir sonuç, özür dilemek ve elde edilecek sonuç arasında hiçte beklenmeyen bir etkinin ortaya çıkmasına yol açarak, özrün anlamının kaybolmasına yol açabilir. ${ }^{87}$ Nitekim hala birçok toplumda özür dilemek o devletin imajına ve hatta ulusal bütünlügüne zarar veren bir şey olarak algılanmakta ve bu durum hem devletlerin özür dilemesini engellemekte hem de dilenen özürlerin samimiyeti ve geçerliliğiyle ilgili şüphelerin ortaya çıkmasına neden olmaktadır.

Özür dilemek konusundaki eleştirilerin ikinci boyutu özrün kendisi, anlamı ve uluslararası ilişkilerdeki pratik değeriyle ilişkilidir. Cunningham'a göre özür, devletlerin bir şeyi telafi etmeden ya da herhangi bir maliyet ödemeden kazanç elde ettikleri siyasal stratejilerinin bir malzemesi haline gelebilir. Bu nedenle son dönemdeki özür çağı konusunda daha ihtiyatlı bir yaklaşım çizen Cunningham, özür dilemenin aslında sonu gelmeyen bir sürece dönüşebileceği (Reductio ad absurdum) uyarısında bulunarak, tarihsel olarak özür dilemeyi gerektiren birçok hadisenin yaşandığını belirtmektedir. Ona göre zaten geçmiş dönemde benimsenen/uygulanan ve fakat içinde yaşadığımız dönemde doğru olarak karşılanmayan bazı şeyler için (kölelik gibi) özür dilemek anlamsızdır. O dönemi bugünün doğrularıyla değerlendirmek gibi anakronik bir hataya düşme ihtimali bulunmaktadır. ${ }^{88}$ Bu eleştirilerin bazı açılardan haklılık payı olsa da, özellikle anakronizm eleştirisi, özrün normatif boyutunda tartıştığımız değeri noktasında anlamsızdır. Çünkü özür dileyen devletin amacı ya da özrün işlevi geçmişi bugünün değerleriyle yargılamak değildir. Özür dilemeye temel teşkil eden konudan dolayı mağdur olmuş tarafların mağduriyetini paylaşmak ve benzer eylemlerin tekrarlanmayacağ 1 konusunda bir anlamda taahhütte bulunmaktır. Normatif olarak eylemin ya da politikanın geçmişteki yeri ve durumunu değil, mevcut ana ilişkin yanlışlı̆̆ını ve doğruluğunu sorgulamaktır.

84 Cunningham, "It Wasn't Us”, s.252-258.

85 Renner, "I'm Sorry for Apologising”, s.1583.

86 Charles L. Glaser, "Historical Remembrance and International Relations Theory", Journal of East Asian Studies, Cilt 9, No.3, 2009, s.341.

87 Lind, "Sorry States", s.12.

88 Cunningham, "Saying Sorry”, s.287-288. 
Özrün anlamı ve uluslararası ilişkilerdeki örneklerini sorgulayan Rajan da, devletlerin diledikleri özürlerle aslında özür dileyen devletin hiyerarşik olarak üst bir pozisyonda yer aldığını aynı zamanda dilenen özürlerin yanlışı ya da suçu geçmişle izole edip bugünle hiçbir bağının olmadığını göstermek için kullanıldığını ileri sürmektedir. ${ }^{89}$ Benzer şekilde Gibney ve Roxstrom da, büyük devletlerin genelde zayıf devletlerden özür dilediğini iddia ederek, bu durumlarda dilenen özürlerin aslında geçmişte yaşanmış olaylar için anlamsız şeyler söylemenin ötesine geçmediğini belirtmektedir. Onlara göre devletlerin güçlü olması, bu devletlere bir anlamda böyle bir lisans vermektedir. ${ }^{90}$ Her iki eleştirinin de pratik örnekler üzerinden değerlendirildiğinde haklılık payları bulunmaktadır. Sahip oldukları güç kapasitelerinde önemli düzeyde farkll1ık olan devletler arasında daha güçlü devletin özür dilemesi, özrün anlamı noktasında bazı tartışmaları beraberinde getirse de değeri açısından büyük önem taşımaktadır. Nitekim görece zayıf devletin geçmişteki yanlı̧ıları nedeniyle güçlü devletler, kuvvet kullanma ya da diğer zorlayıcı önemlere başvurarak maruz kaldıklarını düşündükleri yanlışlığı telafi edecek araçlara sahiptir. Bu tür araçları zaten güçlü devletlere karşı kullanma imkânı kısıtlı olan devletlerden özür dilenmesi son derece normal karşılanmalıdır. Üstelik devletin özür dilememesi için üretebileceği çok farklı mazeretler varken böyle bir özrün dilenmiş olması önemlidir. Başka bir ifadeyle devlet, gerçekten yanlış bir şey yapmadığına inandığı, özür dilemenin ilgili meseledeki hukuki ya da siyasal pozisyonunu zayıflatacağı endişesi taşıdığı, herhangi bir konudaki özrün daha önceki bir takım olaylara da uyarlanarak çeşitli taleplerin doğacağını düşündüğü, iç politikada bazı kesimler tarafından ciddi şekilde tepki çekeceğine inandığı için özür dilememeyi seçebilir. ${ }^{91}$ Örneğin şimdiye kadar Uluslararası Adalet Divanı, bizzat özür talebinde bulunan devletlerin yer aldığı birçok hadisede devletin özür dilemesi gerektiği konusunda bir karar vermediği halde bile özrün normatif değeri açısından da güçlü devletlerin özür dilemiş olması oldukça anlamlıdır. ${ }^{92}$

Devletlerin birçok gerekçeyle özür dilemeyi gerektiren eylem ya da söylemlerden ötürü sorumluluk üstlenmek istememeleri özür dilemeyi zorlaştıran en temel unsurlardan biridir. Bununla birlikte devletler, özür dileyerek de sorumluluklarını azaltmak ya da gölgelemek yolunu seçebilirler. ${ }^{93}$ Özellikle devletin tarihsel olarak ciddi sonuçları olan bir nedenden dolayı özür dilemiş olması, toplumsal ölçekteki sorumluluk ya da suçluluk hissiyatını azaltabilir. Bu durum dilenen özrü anlamsız kılmasa da, konuya ilişkin toplumsal sorumluluk hissiyatının zayıflaması, özür talep eden kesim ya da devletler açısından çok da olumlu olmayan yeni bir durumun ortaya çıkmasına yol açabilir. ${ }^{94}$

89 Rajeswari Sunder Rajan, "Righting Wrongs, Rewriting History?”, Interventions: International Journal of Postcolonial Studies, Cilt 2, No.2, 2000, s.162.

90 Gibney ve Roxstrom, "The Status of State Apologies", s.926.

91 Bilder, "The Role of Apology in International Law", s.467-469.

92 Jérémie Cornut, "Applying Erotetic to the Complex Causal Paths of Apologies in American Diplomacy", SGIR 7th Pan-European International Relations Conference, Stockholm, 9-11 Eylül 2010, s.25.

93 Kampf, "Public (non-) Apologies”, s.2257-2270.

94 Wohl et.al., "A Critical Review of Official", s.78-79. 
Özür konusunda yapılan eleştirilerin üçüncü ve son boyutu özür dilenen tarafla ilişkilidir. Öncelikle özür, daha öncede detaylı olarak tartı̧̧1dığı üzere, yapılan bir hata ya da yanlışlıktan doğan mağduriyeti gidermeye yönelik olarak dile getirilmelidir. Fakat özür eğer doğru şekilde formüle edilmezse, özür dilenen tarafın mağduriyetini gidermek ya da normalleşmesini sağlamak yerine daha da marjinalize olmasını sağlayabilir. Özellikle toplumsal özürlerde özür dilenen kesimin bizatihi dilenen özür nedeniyle o toplum içinde yabancılaşması gibi sonuçlar ortaya çıkmaktadır. ${ }^{95}$ Aynı zamanda özür dileyen tarafın hegemonik bir söylemle geçmişi yeniden canlandırarak özür dilemesi de benzer bir sonucu beraberinde getirebilir. Özür dilenen tarafın kültürel ve toplumsal anlamda dışlanmışlık hissi yaşayacağı, aşağılandığını düşüneceği şekilde özrün dile getirilmemesi gerekmektedir. ${ }^{96} \mathrm{Bu}$ tip sonuçlara yol açabilecek özürler, toplum içinde ya da toplumlar arasındaki diyaloğu olumsuz etkileyerek, dilenen özrün de anlamsızlaşmasını beraberinde getirebilir. ${ }^{97}$

Özür dileyen taraf gerçekten ve samimi şekilde özrü formüle etmiş olsa bile bazı durumlarda dilenen özür kabul görmeyebilir. Bu anlamda özrün anlamlı olabilmesi için sadece belirli kıstaslara uygun şekilde dile getirilmiş olması yeterli değildir. Kampf, birçok durumda dilenen özürlerin ya yetersiz olduğu ya da samimi olmadıkları gerekçesiyle reddedildiğine, bazense kısmi özürlerin bile kabul edildiğine işaret etmektedir. ${ }^{98}$ Ancak buradaki en önemli noktalardan biri, sosyal yaşamdaki özürlerden farklı olarak, kolektif bir zarar ya da mağduriyetin olduğu durumlarda özrü kabul etmeye ve affetmeye yetkili olan kişi ya da kişi grupları kimlerdir sorusunun yanıtıdır. ${ }^{99}$

\section{Sonuç ve Genel Değerlendirme}

Özür dileyen devlete, dilenen özrün içeriğine/etkilerine ve özür dilenen tarafla ilgili tüm eleştirilere rağmen özür dilemek, uluslararası ilişkilerde son çeyrek asırda giderek yaygınlık kazanmaktadır. Literatürdeki “özür çağı, özür patlaması, özür dileme akımı, özür-mania (apology mania)" gibi kullanımların yaygınlık kazanması da bu durumun açık bir göstergesidir. Bununla birlikte bir devletin özür dilemesi ya da geçmişte yapılmış bazı yanlı̧̧lar için sorumluluğunu kabul etmesi, özrün sözel olarak dile getirilmesinden daha fazla anlam ifade eder. Bu noktaya işaret eden ve Türkiye ve Japonya’nın geçmişteki bazı hadiseler nedeniyle özür dilemek konusundaki isteksizliklerini karşılaştırmalı olarak değerlendiren Zarakol da özür dilemenin aslında doğrudan devlet kimliğinde etki doğuran bir unsur

95 Coicaud, “Apology”, s.111.

96 Jan Löfström, "Historical Apologies as Acts of Symbolic Inclusion-and Exclusion? Reflections on Institutional Apologies as Politics of Cultural Citizenship", Citizenship Studies, Cilt 15, No.1, 2011, s.93.

97 Jeff Corntassel ve Cindy Holder, "Who's Sorry Now? Government Apologies, Truth Commissions, and Indigenous Self-Determination in Australia, Canada, Guatemala, and Peru", Human Rights Review, Cilt 9, No.4, 2008, s.466.

98 Zohar Kampf, "The Pragmatics of Forgiveness: Judgments of Apologies in the Israeli Political Arena”, Discourse E' Society, Cilt 19, No.5, 2008, s.592.

99 Peter Digeser, "Forgiveness and Politics: Dirty Hands and Imperfect Procedures", Political Theory, Cilt 26, No.5, 1998, s.719. 
olduğuna dikkat çekmektedir. Özür dilemek ve ontolojik güvenlik arasında bağlantı kurduğu çalışmasında, devlet kimliğinin değişmesinde ve devletin hem kendini tanımlama hem de dünyayı algılama sürecinde ve dünya içindeki pozisyonunu belirleme noktasındaki kaygılarla özür dilemek arasında doğrudan bir ilişki olduğunu vurgulamaktadır. ${ }^{100}$ Devletlerin aslında özür dilemek ya da dilememek konusundaki tutumlarında, Zarakol'un da işaret ettiği üzere, ontolojik güven(siz)lik durumundan çok, "sembolik" anlamda dahi olsa bile özür dilemenin doğuracağ fiziksel güven(siz)liğge ilişkin kaygılar daha belirleyicidir. ${ }^{101}$

Uluslararası ilişkilerde özür dilemenin son çeyrek asırda yaygınlaşmış olması sadece pratikte yaşanan gelişmelerle açıklanamaz. Özür dilemek konusundaki hatııı sayılır düzeydeki literatürün belki de en temel eksikliklerinden biri Uluslararası İlişkiler disiplinindeki gelişmelerle özür dilemenin yaygınlaşması arasındaki bağın yeterince kurulamamış olmasıdır. Oysaki Uluslararası İlişkiler çalışmalarındaki Post-pozitivist dönemdeki kimlik, aidiyet, kültür, farklılık, tanıma, toplumsal cinsiyet, demokratikleşme, marjinalize edilmiş grupların temsili, Soğuk Savaş dönemi söylem ve pratiklerinin sorgulanması gibi unsur ve gelişmelerle devletlerin özür dilemesi arasında tesadüfle açıklanamayacak kadar bir ilişki bulunmaktadır. Disiplinin güvenlik, güç, jeopolitik, egemenlik ve ulusal çıkar gibi "ulvi” konularla meşgul olmuş ajandasındaki bu zenginleşme siyasal alan ve olana ilişkin alg1 ve tanımlarımızı da çeşitlendirmiştir. Bu durumun doğal bir uzantısı olarak da devletler özür dilemenin birçok durumda kendi politik çıkarlarıyla uyuşmadığını bildikleri durumlarda dahi özür dilemeyi tercih edebilmişlerdir.

Disiplinin gündemindeki zenginleşmenin, devletlerin özür dilemesini "kolaylaştırıcı" unsurlardan biri olduğu açıktır. Ancak bu durum tek başına devletin özür dilemesi için yeterli olmayacaktır. Aslında bu çalı̧̧mada da verilen örneklerde de görüleceği üzere devletler, genellikle yapısal olarak (zaman zaman iç yapısal faktörlerin fakat çoğunlukla dış yapısal faktörlerin etkisi/baskısıyla) dönüşüm geçirdikleri süreçte özür dilemektedirler. Örneğin Bulgaristan Meclisi, 2012 y1lında 1980'li yıllarda ülkedeki Türklere yönelik asimilasyon politikası nedeniyle özür dilemiştir. Ulusal Meclis'te kabul edilen bildiride Soğuk Savaş sonrası gelişen insan hakları rejimine vurgu yapılmış olması dikkat çekicidir. Demirtaş, Meclis'in bu özründe her ne kadar AB üyesi olsa da Bulgaristan'ın içinden geçmekte olduğu Avrupalılaşma sürecinin belirleyici olduğunu savunmaktadır. ${ }^{102}$ Bulgaristan örneğinde olduğu üzere devletler geçirmiş oldukları dönüşümlerin bir çıktısı olarak özür dilerler. Bu anlamda özür dilemek, devletin dış politika kimliğinin bileşenlerinin yeniden gözden geçirildiği ve daha barış̧̧1 ve uzlaşmacı bir dış politikanın inşasının bir göstergesi olarak kullanılmaktadır. Bu durum, özellikle disiplinde Yeni Gerçekçilerin devletlerin kapasiteleri ve dış politikaları arasındaki kurduğu ilişkiyi kabul etmeyen İnşacıların argümanlarını da güçlendirmektedir. Nitekim daha önce de vurgulandığı üzere özür dilemek,

100Ayşe Zarakol, "Ontological (In)security and State Denial of Historical Crimes: Turkey and Japan”, International Relations, Cilt 24, No.1, 2010, s.7.

101Jones Shannon, "Apology Diplomacy: Justice for All”, Discussion Papers in Diplomacy, No.122, 2011, s.33.

102Birgül Demirtaş, "Bulgaristan'da Asimilasyon Kampanyası: Geçmişle Yüzleşmek ya da Yüzleşememek”, 21. Yüzyılda Sosyal Bilimler, Cilt 1, No.1, Güz 2012, s.170-171. 
sadece devletlerin dış politika inşalarının sorgulanması noktasında değil ayrıca devletin rasyonalitesine ilişkin Gerçekçi algıların da yeniden gözden geçirilmesine yol açmaktadır.

Devlete dair algılarımızın çeşitlenmesi açısından bu sorgu sürecinin olumlu çıktıları olsa da devletlerin özür dilemesi bir başka açıdan disiplindeki devletin kutsallığına ilişkin yaygın algıyı güçlendirmektedir. Devletlerin özür dilemesi, bu konudaki literatürde şimdiye kadar hiç ele alınmayan, "devletin antropomorfik (insansı) yönünü” ciddi anlamda kuvvetlendirmektedir. İnsana matuf bir takım hasletlerin devletle ilişkilendirilmesi ve devlete dair tüm tanımlamalarda doğalmış gibi gelen bu kullanımlar aslında devletin kutsallığına hizmet etmektedir ki bu durum devlete dair yapılan tartı̧maların disiplinde kısır kalması sonucunu doğurmaktadır.

Uluslararası İlişkiler çalışmalarında yarattığı etkilerin dışında devletlerin özür dilemesi pratik olarak da bazı norm ve değerlerin uluslararası ilişkilerde pekişmesine önemli düzeyde katkı sağlamaktadır. Özür dilemek ve demokratikleşme arasındaki ilişkiyi ampirik olarak ortaya koyan bir çalışma olmasa da, iki husus arasında çok doğrudan bir ilişki olduğu kuramsal olarak ileri sürülebilir. Bir devletin hem içerideki bir takım gruplardan hem de diğer devletlerden özür dilemesi, özür dileyen tarafin kendisiyle hesaplaşması ve sorumluluklarını üstlenmiş olması nedeniyle demokratik bir bilincin kurumsal ve toplumsal ölçekte yerleşmesine de hizmet eder. Kendisiyle hesaplaşamayan bir devletin, demokrasinin en temel ilkelerinden biri olan hesap verebilirlik ilkesiyle uyumlu bir siyasal anlayışı sergilemesi çok da olası değildir.

Devletlerin gerekçesi farklılaşmakla birlikte giderek daha çok özür diliyor olmaları, toplumlar arasındaki bazı gerilimlerin çatışmaya varmadan çözümlenmesinde ya da çatışma sonrası rehabilitasyon sürecinde önemli düzeyde katkı sağlayabilir. Çatışma yönetimi konusundaki literatürün yeterince üzerinde durmadığı bu nokta, bu alandaki çalışmaların zenginleşmesine de katkı yapacaktır. Bu durum aynı zamanda henüz bir taslak halinde olsa da gelecek dönemde uluslararası hukuk ilkesi olarak da özür dilemenin düzenlenmesine yol açabilir. 


\section{Kaynakça}

Andrieu, Kora, "Sorry for the Genocide: How Public Apologies Can Help Promote National Reconciliation”, Millennium: Journal of International Studies, Cilt 38, No 1, 2009.

Barkan, Elazar ve Alexander Karn, "Group Apology as an Ethical Imperative”, Elazar Barkan ve Alexander Karn (der.), Taking Wrongs Seriously: Apologies and Reconciliation, Stanford, Stanford University Press, 2006.

Barkan, Elazar, The Guilt of Nations: Restitution and Negotiating Historical Injustices, Baltimore, John Hopkins University Press, 2000.

Benoit, W. L., Accounts, Excuses, and Apologies: A Theory of Image Restoration, Albany, State University of New York Press, 1995.

Bilder, Richard B., "The Role of Apology in International Law", Mark Gibney (der.), The Age of Apology: Facing Up to the Past, Pennsylvania, University of Pennsylvania Press, 2008.

Bilder, Richard B., "The Role of Apology in International Law", Virginia Journal of International Law, Cilt 46, No 3, 2006.

Brooks, Roy L., "The Age of Apology”, Roy L. Brooks (der.), When Sorry Isn't Enough: The Controversy over Apologies and Reparations for Human Injustice, New York, New York University Press, 1999.

Carroll, Ross, "The Politics of Culpability: Apology and Forgiveness in International Society", http:/www.wiscnetwork.org/ljubljana2008/papers/WISC_2008-184.doc

Caze, Marguerite La, "The Asymmetry between Apology and Forgiveness", Contemporary Political Theory, Cilt 5, No 4, 2006.

Celermajer, Danielle, The Sins of the Nation and the Ritual of Apologies, Cambridge, Cambridge University Press, 2009.

Cohen, Raymond, "Apology and Reconciliation in International Relations", Yaacov B. S. Tov (der.), From Conflict Resolution to Reconciliation, New York, Oxford University Press, 2004.

Coicaud, Jean-Marc, “Apology: A Small Yet Important Part of Justice”, Japanese Journal of Political Science, Cilt 10, No 1, 2009.

Cole, Elizabeth A., "Apology, Forgiveness, and Moral Repair", Ethics and International Affairs, Cilt 22, No 4, 2008.

Corntassel, Jeff ve Cindy Holder, "Who's Sorry Now? Government Apologies, Truth Commissions, and Indigenous Self-Determination in Australia, Canada, Guatemala, and Peru", Human Rights Review, Cilt 9, No 4, 2008.

Cornut, Jérémie, "Applying Erotetic to the Complex Causal Paths of Apologies in American Diplomacy", SGIR 7th Pan-European International Relations Conference, Stockholm, 9-11 Eylül 2010 .

Crawford, James, “Articles on Responsibility of States for Internationally Wrongful Acts", http:// legal.un.org/avl/pdf/ha/rsiwa/rsiwa_e.pdf

Cunningham, Michael, "It Wasn't Us and We Didn't Benefit': The Discourse of Opposition to an Apology by Britain for Its Role in the Slave Trade”, The Political Quarterly, Cilt 79, No 2, 2008.

Cunningham, Michael, "Prisoners of the Japanese and the Politics of Apology: A Battle over History and Memory", Journal of Contemporary History, Cilt 39, No 4, 2004.

Cunningham, Michael, "Saying Sorry: The Politics of Apology", The Political Quarterly, Cilt 70, No 3, 1999.

Cunningham, Michael, "The Ideological Location of the Apology", Journal of Political Ideologies, Cilt 16, No 1, 2011. 
David, Roman ve Susanne Y. P. Choi, "Forgiveness and Transitional Justice in the Czech Republic", The Journal of Conflict Resolution, Cilt 50, No 3, 2006.

Davidow, Jennie, "Methods for Coding Perspectives on Apology and Reconciliation", Kathleen Malley-Morrison et al., (der.), International Handbook of Peace and Reconciliation, New York, Springer, 2013.

Demirtaş Birgül, "Bulgaristan'da Asimilasyon Kampanyası: Geçmişle Yüzleşmek ya da Yüzleşememek”, 21. Yüzyılda Sosyal Bilimler, Cilt 1, No 1, Güz 2012.

Digeser, Peter, "Forgiveness and Politics: Dirty Hands and Imperfect Procedures", Political Theory, Cilt 26, No 5, 1998.

Doods, Graham G., "Governmental Apologies and Political Reconciliation”, Bruno Charbonneau ve Genevieve Parent (der.), Peacebuilding, Memory and Reconciliation: Bridging Top-Down and Bottom-Up Approaches, New York, Routledge, 2012.

Draft articles on Responsibility of States for Internationally Wrongful Acts Adopted by the International Law Commission at its Fifty-third Session (2001) http://www.ilsa.org/jessup/ jessup06/basicmats2/DASR.pdf

Edwards, Jason A., "Apologizing for the Past for a Better Future: Collective Apologies in the United States, Australia, and Canada", Southern Communication Journal, Cilt 75, No 1, 2010.

Edwards, Jason A., "The Mission of Healing: Kofi Annan's Failed Apology", Atlantic Journal of Communication, Cilt 16, No 2, 2008.

Feldman, Lily Gardner, “The Principle and Practice of 'Reconciliation' in German Foreign Policy: Relations with France, Israel, Poland and the Czech Republic”, International Affairs, Cilt 75, No 2, 1999.

Gibney, Mark, Erik Roxstrom, “The Status of State Apologies”, Human Rights Quarterly, Cilt 23, No 4, 2001.

Glaser, Charles L., "Historical Remembrance and International Relations Theory", Journal of East Asian Studies, Cilt 9, No 3, 2009.

Gong, Gerrit W., “The Beginning of History: Remembering and Forgetting as Strategic Issues”, The Washington Quarterly, Cilt 24, No 2, 2001.

Govier, Trudy, Wilhelm Verwoerd, "The Promise and Pitfalls of Apology”, Journal of Social Philosophy, Cilt 33, No 1, 2002.

Hanke, Katja et al., "When the Past Haunts the Present: Intergroup Forgiveness and Historical Closure in Post World War II Societies in Asia and in Europe", International Journal of Intercultural Relations, Cilt 37, No 3, 2013.

Harris, Sandra et al., "The Pragmatics of Political Apologies”, Discourse E̋ Society, Cilt 17, No 6, 2006.

Hassmann, Rhoda E. H. ve Mark Gibney, "Introduction: Apologies and the West", Mark Gibney (der.), The Age of Apology: Facing Up to the Past, Pennsylvania, University of Pennsylvania Press, 2008.

Hassmann, Rhoda Howard, “Official Apologies”, Transitional Justice Review, Cilt 1, No 1, 2012.

Hirsch, Alexander, "Agon of Reconiliation", Alexander Hirsch (der.), Theorizing Post-Conflict Reconciliation: Agonism, Restitution \& Repair, New York, Routledge, 2012.

James, Matt, 'Wrestling with the Past: Apologies, Quasi-Apologies, and Non-Apologies in Canada”, Mark Gibney, et al. (der.), The Age of Apology: The West Faces its Own Past, Tokyo: United Nations University Press 2007.

Jeffery, Renee, "When is an Apology not an Apology? Contrition Chic and Japan's (un)Apologetic Politics”, Australian Journal of International Affairs, Cilt 65, No 5, 2011. 
Joyce, Richard, “Apologizing”, Public Affairs Quarterly, Cilt 13, No 2, 1999.

Kampf, Zohar ve Nava Löwenheim, "Rituals of Apology in the Global Arena”, Security Dialogue, Cilt 43, No 1, 2012.

Kampf, Zohar, "Public (non) Apologies: The Discourse of Minimizing Responsibility", Journal of Pragmatics, Cilt 41, No 11, 2009.

Kampf, Zohar, "The Age of Apology: Evidence from the Israeli Public Discourse", Social Semiotics, Cilt 19, No 3, 2009.

Kampf, Zohar, "The Pragmatics of Forgiveness: Judgments of Apologies in the Israeli Political Arena”, Discourse E' Society, Cilt 19, No 5, 2008.

Lawson, Stephanie, Seiko Tannaka, "War Memories and Japan's 'Normalization' as an International Actor: A Critical Analysis”, European Journal of International Relations, Cilt 17, No 3, 2010.

Lazare, Aapon, On Apology, New York, Oxford University Press, 2004.

Levi, Deborah L., "The Role of Apology in Mediation”, New York University Law Review, Cilt 72, No 5, 1997.

Liebersohn, Yosef Z. et al., "Oh Baby, it's Hard for me to Say I'm Sorry: Public Apologetic Speech and Cultural Rhetorical Resources", Journal of Pragmatics, Cilt 36, No 5, 2004.

Lind, Jennifer, "Apologies and Threat Reduction in Postwar Europe", Memory of Violence Workshop, Massachusetts Institute of Technology, 24-25 Ocak 2003.

Lind, Jennifer, “Apologies in International Politics”, Security Studies, Cilt 18, No 3, 2009.

Lind, Jennifer, "Sorry States: Apologies in International Politics", APSA Meeting, Washington, D.C., 1-4 Eylül 2005.

Löfström, Jan, "Historical Apologies as Acts of Symbolic Inclusion - and Exclusion? Reflections on Institutional Apologies as Politics of Cultural Citizenship", Citizenship Studies, Cilt 15, No 1, 2011.

MacLachlan, Alice, “The State of "Sorry": Official Apologies and their Absence”, Journal of Human Rights, Cilt 9, No 3, 2010.

Macleod, Leslie H., "A Time for Apologies: The Legal and Ethical Implications of Apologies in Civil Cases", Cornwall Public Inquiry, Phase 2 Research and Policy Paper Final Paper, 12 Nisan 2008.

Marrus, Michael R., "Official Apologies and the Quest for Historical Justice”, Journal of Human Rights, Cilt 6, No 1, 2007.

McMillan, Nesam, "Regret, Remorse and the Work of Remembrance: Official Responses to the Rwandan Genocide”, Social E Legal Studies, Cilt 19, No 1, 2010.

Mills, Nicolaus, "The New Culture of Apology", Dissent, Cilt 48, No 4, 2001.

Mitchel, Emily, “Apologies: Who's Sorry Now?”, Index on Censorship, Cilt 27, No 3, 1998.

Moolakkattu, John S., "Remorse and Forgiveness: A Contemporary Political Discussion”, Journal of Social Sciences, Cilt 26, No 1, 2011.

Murphy, Michael, “Apology, Recognition, and Reconciliation”, Human Rights Review, Cilt 12, No $1,2011$.

Nagesh, Girma, Apologia Politica: States E Their Apologies by Proxy, Lanham, Lexington Books, 2006.

Nobles, Melissa, The Politics of Official Apologies, Cambridge, Cambridge University Press, 2008.

Nytagodien, Ridwan ve Arthur Neal, "Collective Trauma, Apologies, and the Politics of Memory", Journal of Human Rights, Cilt 3, No 4, 2004.

Olick, Jeffrey K., The Politics of Regret: On Collective Memory and Historical Responsibility, New York, Routledge, 2007.

Özlük, Erdem, Uluslararası İlişkilerde Devlet: Tanım, Teori ve Devlet İstisnacılı̆̆ı, Konya, Çizgi, 2012. 
Páez, Darío, "Official or political apologies and improvement of intergroup relations: A neo-Durkheimian approach to official apologies as rituals", Revista de Psicología Social, Cilt 25, No $1,2010$.

Petrucci, Carrie J., "Apology in the Criminal Justice Setting: Evidence for Including Apology as an Additional Component in the Legal System", Behavioral Sciences and the Law, Cilt 20, No 4, 2002.

Puls, Darrell, "Where Settlements Cannot Go: Towards a Praxis of Reconciliation in Group Conflicts", http://www.mediate.com/articles/pulsd2.cfm

Rajan, Rajeswari Sunder, "Righting Wrongs, Rewriting History?", Interventions: International Journal of Postcolonial Studies, Cilt 2, No 2, 2000.

Renner, Judith, "I'm Sorry for Apologising': Czech and German Apologies and their Perlocutionary Effects”, Review of International Studies, Cilt 37, No 4, 2011.

Schneider, Carl D., "What It Means to Be Sorry: The Power of Apology in Mediation", Mediation Quarterly, Cilt 17, No 3, 2000.

Shannon, Jones, “Apology Diplomacy: Justice for All”, Discussion Papers in Diplomacy, No 122, 2011.

Smith, Nick, I Was Wrong: The Meanings of Apologies, Cambridge, Cambridge University Press, 2008.

Somani, Alia, "The Apology and its Aftermath: National Atonement or the Management of Minorities?”, Postcolonial Text, Cilt 6, No 1, 2011.

Stamato, Linda, "Peace and the Culture and Politics of Apology", Peace Review: A Journal of Social Justice, Cilt 20, No 3, 2008.

Swoboda, Hannes ve Jan Marinus Wiersma, Politics of the Past: The Use and Abuse of History, PSE, Socialist Group in the European Parliament, 2009.

Taft, Lee, “Apology Subverted: The Commodification of Apology”, The Yale Law Journal, Cilt 109, No 5, 2000.

Tavuchis, Nicholas, Mea Culpa: A Sociology of Apology and Reconciliation, Stanford, Stanford University Press, 1991.

Thaler, Mathias, "Just Pretending: Political Apologies for Historical Injustice and Vice's Tribute to Virtue", Critical Review of International Social and Political Philosophy, Cilt 15, No 3, 2012.

Thompson, Janna, "Apology, Justice and Respect: A Critical Defence of Political Apology", Australian Association for Professional and Applied Ethics 12th Annual Conference, Adelaide, 28-30 Eylül 2005.

Verdeja, Ernesto, "Official Apologies in the Aftermath of Political Violence", Metaphilosophy, Cilt 41, No 4, 2010.

Watts, Arthur, "The Art of Apology", Maurizio Ragazzi (der.), International Responsibility Today: Essays in Memory of Oscar Schachter, Leiden, Martinus Nijhoff Publishers, 2005.

Weyeneth, Robert R., "The Power of Apology and the Process of Historical Reconciliation", The Public Historian, Cilt 23, No 3, 2001.

Wohl, Michael J. A. et al., "A Critical Review of Official Public Apologies: Aims, Pitfalls, and a Staircase Model of Effectiveness", Social Issues and Policy Revierw, Cilt 5, No 1, 2011.

Zarakol, Ayşe, "Ontological (In)security and State Denial of Historical Crimes: Turkey and Japan”, International Relations, Cilt 24, No 1, 2010. 


\section{Summary}

This article deals with the increasing importance of apologizing in international relations in the last three decades. Most states have reconsidered or revised their past policies towards apologizing to both domestic and international actors due to rapid progress in international human rights regimes, democratization across the globe, and the growing impact of public opinion and international influence on foreign policy since the 1970's.

This process has compelled states to prefer one of four options in regards to apologizing for past policy decisions. Some states after coming to terms with the past have rejected their past and concluded that they did not make any mistakes in terms of policy and discourse. Other states have admitted some wrongs done in the past even though they have expressed that there has been no need to apologize. There are other examples where a state admitted that past wrongs have been done and some people have been victimized, but they contend that certain conditions have to be formed in order to eliminate past victimizations and to apologize. In other words, they apologized conditionally. Finally, some states have accepted their past wrongs and apologized without any conditions. Few states fell into this last category and expressed their guilt with full remorse, asked victims for forgiveness, and ensured past mistakes would not be repeated. This is considered a sincere apology.

It may not be perceived as a sincere apology if the apology does not acknowledge past wrongs or if the apology is expressed conditionally. Also, the apology is not considered sincere if the state does not take responsibility for its past, or work to change practices to guarantee that the same policies or discourses will never happen again. For an apology to be considered sincere a state must demonstrate their effort to expose and disclose the truth.

After touching upon debates on definition of apologizing and dimensions of apology, we claim that there are four dimensions of apology: material or practical, normative, pragmatic, and legal.

Material or practical dimension of apology includes publishing official documents, delivering an oral statement of apology, providing compensation, building a monument or commemoration. These forms can also be seen as a symbol of apology. Furthermore, acknowledging and admitting past guilt and how it has been portrayed in public imagination is also important. In other words, how has this acknowledgment or admission been transferred to the next generation and how does collective memory of the nation perceive it? All endeavors such as books, movies, music, museums will be perceived as the part of symbolic forms of apology, because these forms will be helpful to keep the memory of contentious and harmful incidents alive in the nation's history, and make it possible to prevent the same things from happening again.

States can contribute to creating a norm in international relations by apologizing, taking a responsibility for past wrongs, and/or requesting for forgiveness. Any apologies expressed at the right time with the right attitudes and in a productive way can cause positive political effects on reinforcing an existing norm in IR.

States also use apologies as a foreign policy tool for developing the possibility of international cooperation, improving their own image and prestige in the international arena, resolving some problems with other states, or yielding a process of normalization with other states. States, especially while experiencing political transition processes, can benefit from apologizing for evading historical wrongs that have both ethical and social legacies.

Apologizing means that a state accepts the responsibility of wrong doings perpetuated in the past. In terms of legal dimension of apology submitting the case to international court or commission, accepting to pay compensation or judging people who have a direct responsibility concerning the issue can be used as a tool. 
This article also tries to respond to the question "why states apologize?" Many states apologize when it is the only viable option. They apologize for a belief when it may enrich their image and prestige in international society. States apologize because there is a legally binding decision by a third party, international organization, or commission. Other times, states apologize in hope of preventing future disputes with another state about related issues. Finally, states apologize for gaining several kinds of national and international support such as economic, political, and of course social.

Growing numbers of the official apologies for the last three decades and growing demands for apologies and compensation have brought about some controversy in regards to the apology. The skeptic views or doubtful approaches about apologizing can be classified by content and reason of apology. For instance realists argue that to apologize is highly precarious in terms of state's survival. Many scholars claim that the discourse of "age of apology" is exaggerated. They also emphasize that apologizing does not have any practical value from a legal point of view.

Why apologizing became widespread discourse cannot be fully perceived by using only practical reasons in international relations. As we know there are a lot of important correlations that exist between the politics of apology and discussions on identity, culture, difference, recognition, gender, democratization of state and society, questioning the several practices which are still going on in a state's apparatus such as traditions and legacies of Cold War era in the post-positivist tendencies in International Relations discipline.

It is obvious that the richness in the agenda of the discipline paves the way for expressing apology. However I am aware of the fact that this is not enough for explaining why states apologize, but it is said states mostly apologize when they have been passing through structural transformation within their borders. Therefore apologies are used as a tool showing that states are ready to revise their components of foreign policy and seek to make new peaceful and compromising foreign policy. This situation also reinforces the constructivist arguments on correlations between states' identities and making and implementation of foreign policy. Apologizing is not only a simple tool used for questioning the states' foreign policies but also provides opportunity to reassess realist perceptions regarding state's rationality. 